
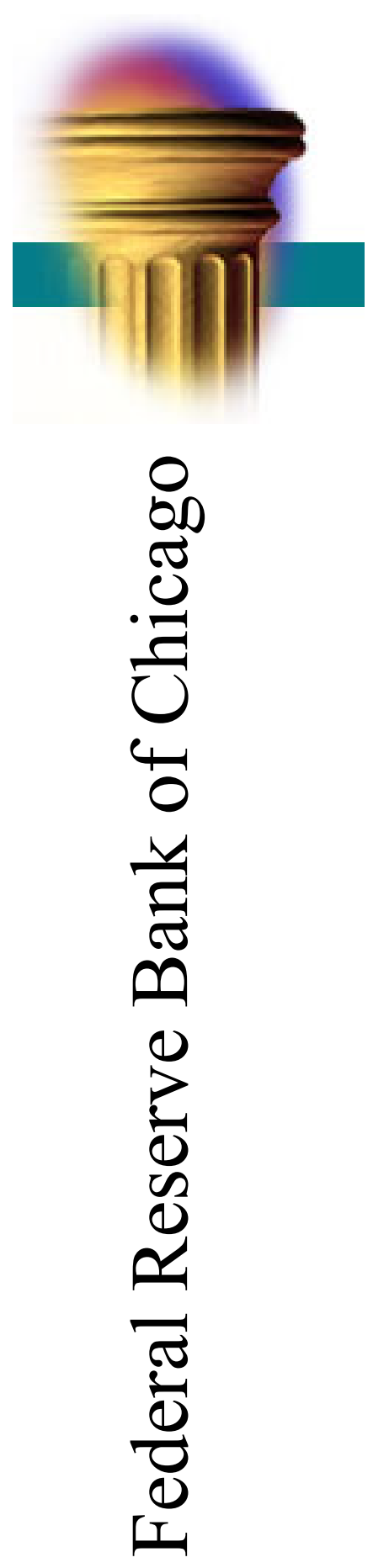

\title{
Has the Willingness to Work Fallen during the Covid Pandemic?
}

\author{
R. Jason Faberman, Andreas I. Mueller, and \\ Ayşegül Şahin
}

February 2022

WP 2022-08

https://doi.org/10.21033/wp-2022-08

${ }^{*}$ Working papers are not edited, and all opinions and errors are the responsibility of the author(s). The views expressed do not necessarily reflect the views of the Federal Reserve Bank of Chicago or the Federal Reserve System. 


\title{
Has the Willingness to Work Fallen during the Covid Pandemic?
}

\author{
February 2022 \\ R. Jason Faberman, Federal Reserve Bank of Chicago* \\ Andreas I. Mueller, UT Austin, CEPR, IZA, and NBER \\ Ayşegül Şahin, UT Austin and NBER
}

\begin{abstract}
We examine the effect of the Covid pandemic on willingness to work along both the extensive and intensive margins of labor supply. Special survey questions in the Job Search Supplement of the Survey of Consumer Expectations (SCE) allow us to elicit information about individuals' desired work hours for the 2013-2021 period. Using these questions, along with workers' actual labor market participation, we construct a labor market underutilization measure, the Aggregate Hours Gap (AHG), following Faberman et al. (2020). The AHG captures changes in labor market underutilization for the full population along both the extensive and intensive margins using data on desired work hours as a measure of their potential labor supply. We find that the sharp increase in the AHG during the Covid pandemic essentially disappeared by the end of 2021. We also document a sharp decline in desired work hours during the pandemic that persists through the end of 2021 and is roughly double the drop in the labor force participation rate. Ignoring the decline in desired hours overstates the degree of underutilization by 2.5 percentage points $(12.5 \%)$. Our findings suggest that, as of 2021Q4, the labor market is tighter than suggested by the unemployment rate and the adverse labor supply effect of the pandemic is more pronounced than implied by the labor force participation rate. These discrepancies underscore the importance of taking into account the intensive margin for both labor market underutilization and potential labor supply.
\end{abstract}

Keywords: labor market slack, Covid pandemic, desired work hours, potential labor supply JEL Codes: E24, J21, J60

* Corresponding author:jfaberman@frbchi.org. We thank Jonas Maibom and various conference and seminar participants for their helpful comments and Elizabeth Kepner and Levi Bognar for excellent research assistance. The views expressed in this paper are our own and do not necessarily reflect the views of the Federal Reserve Bank of Chicago or the Federal Reserve System. 


\section{Introduction}

The Covid pandemic has had a devastating effect on labor markets in the U.S. and throughout the world. Payroll employment in the U.S. fell by as much as 16 percent and remained over 2 percent below its February 2020 level at the end of 2021. The unemployment rate more than quadrupled, rising from 3.5 percent in February 2020 to a peak of 14.7 percent, and was at 3.9 percent at the end of 2021. Several studies, as well as the Bureau of Labor Statistics (BLS, who publish the unemployment rate), have pointed out that even this large spike in the unemployment rate likely understates the degree of labor market slack present during this period. ${ }^{1}$ Moreover, despite a rapid decline in the unemployment rate and relatively strong employment growth since the initial aggregate shock, the labor force participation rate remains persistently low. Economists and the popular press have suggested a broad range of potential causes. These include lagging cyclical adjustment of labor force participation, added child care burdens among women, generous unemployment benefits and other fiscal stimulus programs, fear of returning to work while the virus persists, and structural changes in how individuals view work.

The key to our analysis is the Job Search Supplement of the Survey of Consumer Expectations (SCE). We designed this survey in 2013 and have administered it through the Federal Reserve Bank of New York annually each October since then (see Faberman, Mueller, Şahin, and Topa, forthcoming, for details). The supplement asks a wide range of questions on an individual's employment situation, work preferences, and job search behavior. We focus on questions in the supplement that ask respondents about the number of hours they desire to work and their

\footnotetext{
${ }^{1}$ See, for example, Barnichon and Yee (2020), Faberman and Rajan (2020), Forsythe et al. (2020), Bick and Blandin (2021), as well as the documentation on (mis)measuring unemployment by the BLS at https://www.bls.gov/covid19/effects-of-covid-19-pandemic-and-response-on-the-employment-situation-newsrelease.htm.
} 
reservation wage. These measures allow us to identify changes in willingness to work over time. Furthermore, the 2020 and 2021 SCE Job Search Supplements include new questions on how the pandemic has affected individual job search and labor market participation decisions. Thus, using the SCE for our analysis provides two major advantages. First, unlike traditional surveys, it explicitly asks respondents about their potential labor supply and reservation wages; and second, unlike newer surveys developed during the pandemic, it provides a benchmark period that allows a comparison with the pre-pandemic labor market.

Desired labor supply combined with actual hours worked also provides an intuitive measure of labor market underutilization. We refer to this broader underutilization measure as the Aggregate Hours Gap (AHG) following Faberman, Mueller, Şahin, and Topa (2020, henceforth FMST). The AHG measures underutilization through the difference between individuals' desired work hours and actual hours worked, regardless of labor force status. FMST (2020) show that the SCE measure of desired hours is strongly related to job search effort and is a good indicator of potential labor supply. They also show that the AHG captures aspects of labor market slack missed by traditional measures, like the unemployment rate, and generally has a stronger relationship with nominal wage growth. Given that it encapsulates a broad concept of labor market underutilization, the AHG is well-suited to deal with the unique labor market circumstances of the Covid pandemic. This includes the misclassification of those on furlough or temporary layoff and any reduction in labor supply and work hours for reasons specific to the Covid pandemic and its related lockdown orders.

In this paper, we use the SCE data along with the AHG measure to evaluate and corroborate the impact of the pandemic on labor market underutilization and aggregate labor supply. We find a diverging pattern between the AHG and the unemployment rate. The AHG suggests that the 
labor market is tighter than what the unemployment rate suggests during the Covid pandemic, with the AHG already below its February 2020 level by the end of 2021. We find that this is driven primarily by individuals out of the labor force (and partly by part-time workers). During the pandemic, these individuals report lower desired work hours, and consequently a lower willingness to participate in the labor market even marginally. Quantitatively, we find that the decline in desired work hours across all individuals is 4.6 percent, compared to a decline in the labor force participation rate of 2.3 percent, over this period. The decline occurs with a sharp drop at the onset of the pandemic that remains persistently low thereafter. Further analysis of the decline in the AHG and desired hours shows that a higher share of the employed are essentially on their labor supply curve (in the sense that their actual hours equal their desired hours) and a higher share of those out of the labor force that are unwilling to work at all drive the observed aggregate patterns. Following the Great Recession, the pattern was different. The AHG showed a more sluggish labor market recovery, and therefore a higher degree of labor market underutilization, driven primarily by individuals out of the labor force who were willing to work a small amount of hours but were slow to find work.

To quantify the role of the reduction in labor supply on labor market underutilization, we perform a counterfactual exercise that holds desired work hours constant at their pre-pandemic average within detailed labor force and demographic groups and recalculates the AHG and associated potential work hours from March 2020 forward. The exercise suggests that the decline in desired work hours reduced the AHG by 2.5 percentage points (12.5 percent) relative to its estimated value at the end of 2021. It also suggests that essentially all of the discrepancy between the fall in potential work hours and the labor force participation rate is accounted for by the decline in desired hours during the pandemic (as opposed to changes in composition). Again, changes in 
the desired hours of those out of the labor force and part-time workers account for most of the differences identified in the counterfactual exercise. Notably, we find only mild differences by gender in their declines in desired hours-i.e., the result is not driven by a contraction in labor supply among women which resonates with the findings of Hobijn and Şahin (2021). Instead, we find the drop in desired hours is pervasive across most demographic groups, with those with less than a college degree having a notably larger contribution.

Finally, we examine a range of suggestive evidence on the extent that the Covid pandemic had a direct role on the observed reduction on labor supply. First, we group individuals based on the degree of social contact required of their current or most recent job, with a higher degree of social contact implying a higher potential exposure to Covid. We find that individuals in jobs with at least a moderate degree of social contact had sizable reductions in their desired work hours during the pandemic, while those in jobs with a low degree of social contact actually increased their desired work hours. Second, we find that real reservation wages increased during the pandemic for nearly all labor force and demographic groups, consistent with a decline in willingness to work. Real reservation wages increased 6 log points ( 6.2 percent), on average, across all individuals. Third, using the responses to special Covid-specific questions in the CPS and SCE, we find that the pandemic caused a sizeable reduction in job search behavior for most of 2020, but that its effect on job search had mostly subsided by the end of 2021. In fact, we find that job search effort (in terms of job applications sent and the incidence of on-the-job search) rebounded strongly in 2021.

Our study follows an expansive set of empirical studies on the effects of the Covid pandemic on the labor market. Many of these studies focus on the initial shock to the labor market at the onset of the pandemic, while others evaluate the effects of government policies, such as the 
expansion of unemployment insurance, on labor supply and employment. ${ }^{2}$ Most relevant to our research are several studies that find labor market tightness was greater than what standard measures implied because of a reduction in job search effort in the early portion of the pandemic. These include studies by Forsythe et al. (2020), Marinescu, Skandalis, and Zhao (2020), Brinca, Duarte, and Faria-e-Castro (2021), and Hensvik, Le Barbanchon, and Rathelot (2021). These studies identify a reduction in job search effort, either directly or indirectly, as a contributor to labor market tightness across multiple countries. Our findings are consistent with recent work, such as Domash and Summers (2022) and Crump et al. (2022), that argue that the U.S. labor market at the end of 2021 is tighter than in 2019 using alternative measures of labor market tightness. Our study is also related to research on a declining trend in the willingness to work that predates the pandemic (Barnichon and Figura, 2016). Finally, our study dovetails with academic research (e.g., Bick and Blandin, 2020) and government initiatives, such as the U.S. Household Pulse Survey, that developed special surveys and survey instruments to study the Covid pandemic.

The next section describes the conceptual underpinnings of the AHG. Section 3 describes our data and methodology for estimating the AHG and its components. Section 4 presents the aggregate time-series behavior of the AHG and its components. Section 5 quantifies the role of labor supply for the reduction in the AHG and provides supporting evidence on the role of the Covid pandemic for labor supply and job search. Section 6 concludes.

\section{The Aggregate Hours Gap as a Measure of Underutilization}

Labor market underutilization is broadly defined as the ratio of the gap between actual and potential labor and potential labor supply:

\footnotetext{
${ }^{2}$ A sampling of these studies include Bartik et al. (2020), Cajner et al. (2020), Ganong, Noel, and Vavra (2020), Goolsbee and Syverson (2020), and Şahin, Tasci, and Yan (2021).
} 


\section{$\frac{\text { Gap }_{t}}{\text { Labor Supply }}$.}

For example, consider the official (U3) measure of the U.S. unemployment rate, produced by the Bureau of Labor Statistics (BLS). It is equal to the number of unemployed individuals divided by the total number of individuals in the labor force (employed plus unemployed). The gap is the number of people who want a job and have actively looked (and are available) for one, or are on temporary layoff. ${ }^{3}$ Total labor supply is measured as the number of people who either have a job or want a job. ${ }^{4}$ Both measures implicitly give all of these individuals a weight of one when calculating their contribution to labor market underutilization and ignore the variation along the intensive margin of hours.

Given the importance of hours as a measure of total labor input in production, one can define a broader measure, the Aggregate Hours Gap (AHG). FMST (2020) define the measure as:

$$
A H G_{t}=\frac{\sum\left(L_{i t}-h_{i t}\right)}{\sum L_{i t}} .
$$

Its denominator is a measure of potential labor supply that aggregates the total amount of desired work hours at time $t$ across all individuals $i, \sum L_{i t}$, regardless of their labor force status. Its numerator is the desired hours gap, $\sum\left(L_{i t}-h_{i t}\right)$, which captures the difference between desired work hours and actual work hours, $h_{i t}$, and sums this difference across all individuals, regardless of their labor force status. Individuals who are nonemployed but wish to work add to labor market underutilization based on the amount of hours they prefer to supply. Those who are employed but prefer more work hours add to underutilization based on the difference between their current and

\footnotetext{
${ }^{3}$ Temporary layoffs fit this notion of a gap, because individuals would work their usual hours if they were not on layoff. This is a particularly important distinction during the Covid pandemic.

${ }^{4}$ This notion of underutilization also holds for the BLS "U6" measure of underutilization. For the U6 measure, the gap includes all unemployed plus all those who are "marginally attached" to the labor force but not actually a part of it and those who report that they are part-time rather than full-time for economic reasons.
} 
preferred hours. ${ }^{5}$ Consequently, the AHG depends critically on the measures of desired hours and work hours used in its estimation. FMST (2020) show that a self-reported measure of desired work hours is a viable measure of labor supply. There is a strong positive relationship between an individual's desired work hours and their realized job search effort, and there are intuitive relationships between individuals' demographic characteristics, their labor market transitions, and their desired hours. Thus, the AHG has a clear interpretation as a measure of labor market underutilization, and the empirical evidence suggests that a direct measure of desired hours is a valid measure of labor supply. Individual work hours are the obvious measure for $h_{i t}$, but as we discuss below, the use of usual versus actual hours worked, and how we address measurement concerns in work hours, are critical for generating consistent estimates of the AHG during the Covid pandemic. In normal times, the use of usual hours smooths out idiosyncratic hours changes due to illness, vacations, labor stoppages, and the like. During the pandemic, reported actual hours worked, despite including such changes for idiosyncratic reasons, also include changes for reasons specific to the pandemic and therefore capture important measurement issues and labor market behavior that we want our AHG estimates to address.

\section{Data and Measurement}

\subsection{Data Sources}

We build on FMST (2020) to generate our estimates of the AHG, with several notable deviations. We rely on two data sources for our analysis. The first is the Current Population Survey (CPS). The CPS is the survey used to calculate the official U.S. unemployment rate and related

\footnotetext{
${ }^{5}$ While we mostly abstract from their contribution in this paper, it is worth noting that FMST (2020) show that individuals who work more than their desired work hours also exert substantial job search effort, suggesting that their (negative) desired hours gaps are likely also a form of labor underutilization.
} 
labor force statistics. We use the monthly data from January 1994 through December 2021, though we focus much of our analysis on the most recent years for obvious reasons. ${ }^{6}$ We estimate the share of the total population within detailed labor force states and measure desired hours gaps within each labor force state using the monthly CPS data.

Our second data source is the Job Search Supplement to the Survey of Consumer Expectations (SCE) administered by the Federal Reserve Bank of New York. FMST (Forthcoming) developed this supplement in earlier work and the supplement has been administered annually each October since 2013. The supplement asks a broad range of questions on one's current employment state, job search activity, employment history, and work preferences (e.g., reservation wage, desired work hours). These include many questions that are comparable to those in the CPS, allowing us to directly measure variables related to labor force status, hours worked, and other characteristics important for our analysis identically across both data sets. Our SCE sample spans 2013 through 2021. We focus on reported differences in desired work hours between the 2013-19 period and the 2020-21 period. Throughout our analysis, it is important to remember that the SCE data are for October of each year, so the 2020 survey elicits responses about six months after the initial spike in Covid cases and lockdown period, while the 2021 survey elicits responses between the major waves of the delta and omicron Covid variants and during a period of relatively strong labor market growth.

The 2020 and 2021 SCE Job Search Supplements have additional survey questions that focus on issues specific to the Covid pandemic. These include follow-ups to its questions on reasons for not looking for work and reasons for part-time search that elicit whether the Covid pandemic accounted for these reasons and in what way (e.g., child care issues, fear of contracting the virus,

\footnotetext{
${ }^{6}$ We only go back to 1994 because it is difficult to produce a consistent measure of our detailed labor force categories, particularly for those out of the labor force, prior to the 1994 CPS redesign.
} 
caring for someone who was sick, etc.). The new questions also ask about schooling, online learning, and other aspects of the household that may affect the respondent's labor supply decision. We relate this evidence to the behavior of the AHG at the end of our analysis.

We focus on a sample of individuals aged 18 to 79 with nonmissing data on labor force status and broad demographics (age, gender, race, education, marital status) since these are the individuals we can observe in both the SCE and CPS. The CPS is a fairly large sample of about 60,000 households per month. The SCE, however, is much smaller. The Job Search Supplement averages just under 1,200 respondents per year. ${ }^{7}$ We use a sample that pools individuals across all survey years to generate most estimates of the labor market measures described below, but in our estimation of the AHG, we split out our desired hours estimates between the 2013-19 and 202021 periods. This requires us to make some additional adjustments to deal with small sample cell issues.

\subsection{Estimating Desired Hours}

Our desired work hours measure comes from the SCE Job Search Supplement. Specifically, the survey question asks,

"Assuming you could find suitable/additional work, how many hours PER WEEK would you prefer to work on this new job?"

The survey only asks this question to individuals who responded that they actively looked for work or stated that they would or "might" take a job if offered to them. For those who consequently do not have a response, we assign them their total usual hours worked if they are employed and zero desired hours if they are out of the labor force. We do this on the assumption that, for each group,

\footnotetext{
${ }^{7}$ Complicating our analysis is a relatively low response rate in 2020 due to the pandemic, when the survey has only 965 respondents.
} 
their current hours equal their desired hours since their behavior reflects zero desire to change their current work situation. These adjustments generally impute a zero desired hours gap to these individuals. ${ }^{8}$

We match our SCE estimates of desired work hours to individuals in the CPS using their demographics and detailed labor force status. We divide individuals into one of nine labor force states. Four of these represent the employed, which we distinguish by whether they are part-time or full-time, and within each of these categories, whether or not they are a multiple jobholder. We identify the unemployed based on the standard CPS definition (those who want work, have actively searched and are available for work, plus those on temporary layoff), and distinguish them by whether they are short-duration job seekers (looking for 6 months or less) or long-duration job seekers (looking for more than 6 months). Finally, we distinguish those out of the labor force by whether they state wanting work (but otherwise fail to meet the criteria for unemployment), are retired, or are out of the labor force for some other reason (disabled, attending school, or otherwise not working or not wanting work).

Within each labor force state, we categorize individuals based on their gender, age, and education, splitting them into one of three age groups (18 to 24,25 to 54 , and 55 or older) and two education groups (less than a college degree, and a college degree or more). This approach potentially creates up to 108 cells of desired hours estimates, but many of these cells are too small in the SCE data. We therefore follow the approach of FMST (2020) where we aggregate these into an unbalanced panel of 39 labor force status $\times$ demographics cells based on their cell size and similarity of reported desired hours. All labor force states are at least disaggregated by gender, and larger categories are disaggregated further by age group and education as the data allow. The most

\footnotetext{
${ }^{8}$ The exceptions are individuals whose actual hours deviate from their usual hours, which we deal with separately.
} 
disaggregated category is the full-time employed with a single job (10 out of 12 demographic categories), and the least disaggregated categories are the part-time employed with multiple jobs, the short-term and long-term unemployed, and those who are out of the labor force but want work (each only disaggregated by gender).

We estimate these cells separately for the 2013-19 and 2020-21 periods. This creates withincell estimates of desired work hours that vary before and during the pandemic, but are otherwise time-invariant. Aggregate estimates of desired work hours will additionally vary each month due to changes in the population shares across labor force states and demographic groups. ${ }^{9}$ We report the desired hours estimates for each specific cell and period in Appendix Table A.1.

We must also deal with the issue that the 2020 and 2021 surveys, while pooled together, have relatively small sample cells for several of the labor force status $\times$ demographics categories. We deal with this by generating predicted estimates of desired hours for each individual using a regression of their reported desired hours on fixed effects for their demographics, nine-state labor force status, and interactions of their demographics and labor force status with each other and a dummy variable for the 2020-21 period. We then calculate the mean desired hours for each of our 39 labor force status $\times$ demographics categories separately for the 2013-19 and the 2020-21 periods by calculating the (sample-weighted) mean of the predicted values from this regression. This approach reduces the effects of outliers and sampling error on the SCE estimates that we match to the CPS data.

Formally, we pool $i$ individuals together across the $t$ years of the SCE survey and regress their reported desired hours, $L_{i j t}$, on a set of dummy variables for their detailed labor force state

\footnotetext{
${ }^{9}$ FMST (2020) provide a more thorough examination of the demographic disaggregation of these categories, and explore the potential effects on the AHG of using time-varying estimates of desired hours that they derive from the relation of desired hours to aggregate labor market conditions. They find time-varying estimates of desired hours amplify the cyclicality of the AHG but otherwise preserve its qualitative time-series behavior.
} 
$j$, their gender, age (using the three categories above), education (high school or less, some college, college or more), race (White, Black, Hispanic, all other), marital status (married or not), an interaction between gender and marital status, and indicator for year $\geq 2020$, and interactions with this year indicator with the other dummy variables. ${ }^{10} \mathrm{We}$ also include interactions between each individual's broader labor force state (employed, unemployed, out of the labor force) and their gender, age, education, race, and marital status, but do not further interact these with the year indicator to avoid overfitting given our relatively small sample size.

Denote the regression's predicted values for each individual as $\hat{L}_{i j t}$. The estimated desired hours for our set of 39 labor force status $\times$ demographics groups is $\tilde{L}_{d j t}$, which is the sampleweighted mean of $\hat{L}_{i j t}$ for individuals within that group, and where $d$ represents the demographic group defined by gender, age, and education.

\subsection{Estimating Hours Gaps}

We define the desired hours gap as the difference between desired work hours and actual work

hours. We estimate this gap after matching our estimates of desired hours, $\tilde{L}_{d j t}$, to individuals in the CPS by year, detailed labor force status, and demographics (gender, age, and education) for all individuals in our CPS sample (i.e., all age 18 to 79 between January 1994 and December 2021). The desired hours gap is then the difference between this estimate and the CPS respondent's actual work hours, $h_{i j t}$, which we sum across all jobs reported by individual $i$.

\footnotetext{
${ }^{10}$ We topcode our individual-level measures of desired hours in the SCE at 80 hours per week to avoid adverse effects of any outliers. When we match our estimates to the CPS data, we do the same for total actual hours worked.
} 
We adjust the desired hours at the individual level to impose the constraint of a zero minimum hours gap. ${ }^{11}$ Specifically, adjusted desired hours are

- $\quad L_{d(i) j t}=\tilde{L}_{d j t} \quad$ for all non-employed, and

- $\quad L_{d(i) j t}=\max \left\{\tilde{L}_{d j t}, h_{i j t}\right\}$ for all employed.

The resulting desired hours gap for each individual in the CPS in month $t$ is $L_{d(i) j t}-h_{i j t}$. Note that our use of actual hours worked deviates from the approach of FMST (2020), who use usual hours worked. The actual hours measure captures many transitory changes that are unique to the pandemic and not captured by usual hours. As others, including the BLS, have pointed out, there was also considerable labor force misclassification during the pandemic. Many furloughed individuals reported themselves as employed and on leave rather than on temporary layoff (and therefore unemployed).

By using actual work hours in the AHG estimation, we are able to address the misclassification issues that plagued the CPS during the Covid pandemic. Unfortunately, we may also incorrectly attribute hours reductions due to vacations, illness, or other types of leave to labor market slack. We deal with this by further adjusting the desired hours gap estimate for any individual who reports being employed but on leave (regardless of whether the leave was paid or unpaid). If an individual in the CPS reports that they were on leave due to vacation, maternity or paternity leave, schooling or training, civic or military duty, a labor dispute, or weather, we keep their desired hours equal to $L_{d(i) j t}$, but use their usual hours worked as their measure of $h_{i j t}$. We do this because these reasons for leave generally involve idiosyncratic events that are in the control of both the worker and the firm (e.g., through the bargained labor contract or lack thereof) or neither the worker and the firm,

\footnotetext{
${ }^{11}$ FMST (2020) show that individuals with negative hours gaps tend to exert significant search effort, consistent with the behavior of those with positive hours gaps. This suggests that, if anything, these individuals should not reduce the amount of aggregate labor market slack.
} 
and generally do not reflect a reduction in labor supply alone. If an individual reports they are on leave because of child care issues, family obligations, or their own temporary illness, we set their desired hours to their reported actual hours, which equals zero in the absence of work at an additional job. This implicitly sets the hours gap to zero as well. We do this because these instances reflect a reduction in labor supply, though potentially involuntary, for reasons outside of what the worker and firm could contract over. These adjustments affect about 3.5 percent of employment, and has a modest effect on the hours gap of the employed, though the adjustment is particularly important during the Covid pandemic since there is a large spike in individuals who report themselves on leave during this period. The BLS provides evidence that those on furlough who misreport themselves as employed identify themselves as on leave for "other reasons," which is a category that we specifically do not adjust for this reason. ${ }^{12}$

\subsection{Deriving the Aggregate Hours Gap}

We use our micro-level estimates of desired work hours and the resulting hours gaps to derive our monthly estimates of the Aggregate Hours Gap (AHG). Recall from Section 2 that one can define a typical measure of labor market underutilization as the ratio of some gap to a measure of potential labor supply. The AHG uses population share estimates for each of the nine detailed labor force states described above and weights them using a measure of the average desired hours gap within each category.

Define the share of the population in labor force state $j$ in month $t$ as $\omega_{j t}$, with $\sum_{j} \omega_{j t}=1$.

The gap is the sum of these population shares in each state $j$ weighted by its average desired hours gap, $L_{j t}-h_{j t}$. Similarly, our measure of potential (desired) work hours is the sum of these

\footnotetext{
12 The mismeasurement issue is also examined in detail by Faberman and Rajan (2020) and Forsythe et al. (2020).
} 
population shares weighted by their desired hours alone, $L_{j t}$. We interpret the potential hours measure as an estimate of potential labor supply.

We aggregate these gaps within each labor force state as

$$
L_{j t}-h_{j t}=\sum_{i \in j} \frac{\omega_{i j t}}{\omega_{j t}}\left(L_{d(i) j t}-h_{i j t}\right) .
$$

That is, the mean desired hours gap for labor force state $j$ in month $t$ is the population-weighted mean calculated across all individuals in $j$, where $\omega_{i j t}$ is the share of the population made up by individual $i$ (i.e., the respondent's sample weight) and $\omega_{j t}$ is the share of the population in labor force state $j$ in month $t$. We calculate both using the monthly CPS data. Note that the gap measure within labor force state $j$ will vary over time due to changes in the demographic composition of those in state $j$, and among the employed, changes in actual hours worked. It will also change due to changes in desired hours within each category over time, though in our implementation $L_{d(i) j t}$ will only differ before and during the Covid pandemic. Similarly, potential hours is

$$
L_{j t}=\sum_{i \in j} \frac{\omega_{i j t}}{\omega_{j t}} L_{d(i) j t}
$$

Potential hours within labor force state $j$ will also vary over time due to changes in the demographic composition of those in state $j$ and due to changes in desired work hours within each category before and during the pandemic. Plugging the measures for the desired hours gap and potential work hours into equation (1) implies that the AHG measure is

$$
A H G_{t}=\frac{\sum_{j} \omega_{j t}\left(L_{j t}-h_{j t}\right)}{\sum_{j} \omega_{j t} L_{j t}}
$$

The numerator of equation (3), the gap, will vary over time due to the demographic, work hours, and desired hours variation noted above, as well as variations in the population share of each labor force state $j$. The denominator of equation (3), potential work hours, will vary over time due to the 
demographic and desired hours changes noted above, and changes in the population share of each labor force state $j$.

\section{Evidence on the Aggregate Hours Gap and Desired Hours}

\subsection{The Aggregate Hours Gap over the Business Cycle}

We start by presenting the aggregate time-series evidence for the Aggregate Hours Gap (AHG) and potential work hours (i.e., potential labor supply). Figure 1 presents the time-series of the AHG and compares it to the cyclical behavior of the unemployment rate. The AHG and the unemployment rate track each other closely through the Great Recession, but diverge thereafter, with the AHG implying a persistently higher level of underutilization following the Great Recession. This divergence is notably absent during the Covid pandemic, a point we return to shortly.

Figure 2 compares the cyclical behavior of potential (desired) work hours and the labor force participation rate. Again, the two series track each other closely through the Great Recession. There is a brief divergence following the Great Recession, with potential work hours falling faster than the participation rate, but the two series converge by 2014. The two series both exhibit large persistent drops during the Covid pandemic. Their declines are quite different quantitatively, however, with potential work hours falling about twice as much as the participation rate. By the end of 2021, the labor force participation rate is about 2.3 percent lower than its February 2020 level while potential work hours are about 4.6 percent lower than their February 2020 level. The impact of the sharp decline in desired work hours will be a recurring theme throughout our analysis. 
Figure 3 examines the differential behavior of the $\mathrm{AHG}$ and the unemployment rate in more detail. The top panel normalizes each measure to its 2007 average and plots its behavior during and after the Great Recession. They key feature is the persistently higher level of labor market underutilization implied by the AHG relative to the unemployment rate. By the end of 2015, the unemployment rate is nearly back to its pre-recession level, while the AHG is still 2.1 percentage points above its pre-recession level.

The bottom panel of Figure 3 normalizes the two measures to their 2019 averages and shows that this pattern is practically reversed during the Covid pandemic. Both measures spike sharply at the onset of the pandemic and fall sharply thereafter. By the end of 2021, however, the AHG is slightly below its pre-recession level while the unemployment rate remains somewhat above its pre-recession level. As we show in the next section, the key driver of the divergent behavior in both cases is the movement in desired work hours over time.

Figure 4 shows the changes in the AHG over time by its detailed labor force components, with employment components in the first panel, unemployment components in the second panel, and out of the labor force components in the last panel. Each component is equal to its population share multiplied by its gap contribution, all divided by mean potential work hours across all individuals. This ensures that the sum of the components across all labor force states equals the AHG estimate depicted in Figure 1. The first panel of Figure 4 shows that multiple jobholders contribute a negligible amount to movements in the AHG. Those with a single full-time or parttime job exhibit a notable hours gap throughout the sample period, though their cyclical movements during the Great Recession were relatively modest. In contrast, the full-time employed exhibit large and uneven spikes in their hours gaps during the Covid pandemic. These spikes primarily reflect workers who are furloughed or have had their hours otherwise cut due to business 
closures and cutbacks from multiple waves of Covid cases. ${ }^{13}$ These individuals remain employed (as defined in the CPS survey) and prefer to work at their usual hours, but have their actual hours cut, leading to an increase in their hours gaps. Part-time workers exhibit a notable decline in their hours gap during the pandemic. The decline persists through the end of 2021 and contrasts with the slight rise in the hours gap for part-time workers during the Great Recession. We show in the next section that a fall in desired work hours (rather than a rise in hours worked) among part-time workers is a key driver of the decline.

The second panel of Figure 4 shows the hours gaps of the short-term unemployed (those unemployed 6 months or less) and long-term unemployed (those unemployed more than 6 months). The two series closely parallel the behavior of the short-term and long-term unemployment rates in the CPS. This is because both groups report desiring close to full-time work hours, and this preference changes little during the pandemic. Consequently, the unemployment components of the AHG contribute significantly to its cyclical movements over time, but explain almost none of the AHG's divergence with the (overall) unemployment rate.

Finally, the last panel of Figure 4 reports the hours gaps of our three out of the labor force categories: those who want work, the retired, and all others. Three facts stand out. First, those who are out of the labor force for other reasons exhibit a large and persistent drop in their hours gap during the pandemic. As we show in the next section, this reflects a large decline in their desired work hours. Second, those who are out of the labor force but report wanting work exhibit a large and persistent spike in their hours gap during the pandemic. This is driven primarily by movements in the share of individuals who are out of the labor force but want work during this period, and less so by changes in their desired hours. The contribution of this group to the AHG rose during the

\footnotetext{
${ }^{13}$ Goolsbee and Syverson (2021) were among the first to show that changes in economic activity followed changes in local Covid case rates more than changes in government shutdown order.
} 
Great Recession as well, but not nearly to the sharp and large degree that it does during the pandemic. Lastly, the contribution of the retired follows a steadily rising trend throughout the sample period. This trend is practically undisturbed during the pandemic. ${ }^{14}$

\subsection{The Behavior of Desired Hours}

We next show how desired hours in the SCE data have changed during the pandemic for various subgroups on the data. Table 1 reports the mean estimates of desired work hours for 201317, 2018-19, and 2020-21, along with the difference in desired hours between 2018-19 and 20202021, by detailed labor force state and selected demographics. ${ }^{15}$ The table shows that, prior to 2020, those who work full-time generally prefer full-time hours and those working part-time generally prefer fewer hours. The unemployed, regardless of their duration, generally prefer fulltime hours, on average. Those out of the labor force that report "wanting work" (but either did not actively search or were not available for work) prefer close to full-time hours (about 30 hours per week), but fewer hours than the unemployed, on average. Those who are retired or out of the labor force for other reasons prefer a small but nontrivial amount of work hours, generally between one and two days per week of work. Table 1 also shows that desired hours fell, on average, during the Covid pandemic across nearly all labor force states and for all reported demographic groups. ${ }^{16}$ Within labor force states, the declines were largest among part-time workers (3.1 hours, or 11.5 percent) and those out of the labor force who either want work ( 2.5 hours, or 8.4 percent), or were

\footnotetext{
${ }^{14}$ Several studies, such as Atkinson et al. (2021), and Nie and Yan (2021) highlight a strong potential role for retirements in explaining the persistently low labor force participation rates. While we find a strong role for those out of the labor force in explaining the low rates, we find that the main drivers are those out of the labor force for other reasons, particularly when one accounts for changes in desired hours among individuals.

${ }^{15} \mathrm{We}$ impose that the desired hours of the employed do not imply a negative hours gap, so that the estimates are as comparable to the adjustments we make when estimating the AHG as the SCE data allow.

${ }^{16}$ Note that, in unreported results, we find that desired hours are similar for both 2020 and 2021, despite a strong rebound in the labor market during 2021. Consequently, our results are little changed if we examine changes for these years separately, but statistical precision declines considerably because of our small sample sizes in the SCE.
} 
otherwise out of the labor force for reasons besides retirement ( 3.3 hours, or 22.8 percent). The full-time employed and the unemployed exhibit almost no change in their desired work hours. Returning to the patterns we observe in Figure 4, these results imply that movements in the AHG for full-time workers reflect changes in the share of individuals working full-time as well as changes in their actual work hours-i.e., changes in their desired work hours have little effect on their behavior. Movements in the AHG for the unemployed only reflect changes in the share of individuals who are unemployed because their desired hours are relatively constant as well. The results also shed light on why the AHG for part-time workers falls during the pandemic - those who remain part-time employed prefer fewer work hours during the pandemic. The AHG for those who are out of the labor force but "want work" spikes up and remains elevated throughout the pandemic. This is because the increase in the population share for this group more than offsets the fact that individuals in this group prefer fewer work hours, which would otherwise give them a smaller hours gap. Finally, those who are out of the labor force for other reasons (besides retirement), exhibit a sharp drop in their AHG contribution almost entirely because of a major decline in their desired work hours. The results for those out of the labor force are consistent with the cyclical behavior of participation documented by Hobijn and Şahin (2021). We complement their findings by highlighting the importance of intensive hours adjustments that accompany extensive-margin participation movements.

The results by demographics show that desired work hours fell for all groups save for the college educated. Men had slightly smaller reductions in desired hours compared to women, likely because of added child-rearing burdens falling disproportionately upon women during the Covid pandemic. ${ }^{17}$ In special questions fielded in the SCE Job Search Supplement in 2020 and 2021, we

\footnotetext{
${ }^{17}$ Alon et al. (2020) discuss the disproportionate impact the initial shock of the Covid pandemic had on women's employment and discuss its potential implications in the medium-run.
} 
find evidence consistent with added child care burdens for women during the pandemic. Specifically, we find that in October 2020, about 83 percent of households report having their children's schooling at least partly affected by Covid, and that women report spending an average of 8.4 hours per week on their children's schooling, compared to 5.7 hours reported by men. In October 2021, 36 percent of households report schooling at least partly affected by Covid, with women spending 3.0 hours and men spending 2.6 hours per week on their children's schooling. Among the other demographic groups, only those with less than a college degree exhibit a notably larger decline in their desired hours than the other groups.

Figure 5 reports the distributions of desired work hours by broad labor force status, as well as the implied hours gap for the employed (desired work hours and the hours gap are equivalent for the nonemployed, since they work zero hours). We report the distributions of the unadjusted desired hours from the SCE. Consequently, the employed can have a negative hours gap if their desired work hours are less than their actual work hours. Our method for deriving the AHG essentially sets these negative gaps to zero, as noted earlier.

Figure 5 reports the distributions of desired hours and hours gaps for the pre-pandemic SCE data (2013-19) and the pandemic-period data (2020-21). The distributions of hours gaps for the employed become more kurtotic during the pandemic. That is, there is a higher share of fulltime and part-time workers who report working exactly the hours they prefer and lower shares of workers reporting either a positive or negative hours gap. For full-time workers, this arises through a slightly higher share of them preferring full-time work of 35 hours or more. For part-time workers, this arises through a lower share of them preferring full-time work despite working parttime. The unemployed have essentially no change in the distribution of their desired work hours during the pandemic. Those out of the labor force, however, are much more likely to prefer no 
work at all during the pandemic, and much less likely to prefer some part-time work. The fraction of those out of the labor force who prefer zero work hours rises from 41 percent to 50 percent during the pandemic.

Thus, the Covid pandemic is characterized by a notably large contraction in labor supply. The contraction is concentrated among part-time workers and those out of the labor force who would normally prefer at least some part-time work. We characterize these changes as being concentrated along the intensive margins of labor force participation. These are individuals who are normally only marginally attached to the labor force, in the sense that they work infrequently, and when they do, they prefer less than full-time work. During the pandemic, we find that many of these individuals chose to remain out of the labor force and not work at all. We find little variation across demographic groups, save for that the decline in desired work hours appears concentrated among the less educated.

\section{The Covid Pandemic and Labor Supply}

In the remainder of the paper, we quantify the effect of the decline in labor supply on the AHG and provide supporting evidence for the specific role the Covid pandemic plays in the observed reduction in desired work hours.

\subsection{Quantifying the Role of Lower Labor Supply}

We start with a counterfactual analysis that quantifies the effect of the reduction in desired work hours on the AHG. When we construct our AHG measure, we allow for essentially a discrete change in (predicted) desired work hours within our 39 labor force x demographic estimation cells. Our counterfactual exercise simply holds these cell estimates constant at their 2013-19 values and then recalculates the AHG from March 2020 forward. Under this approach, the counterfactual 
AHG estimates over this period show what the level of labor market underutilization would be had there been no change in desired work hours. The difference between our baseline and counterfactual AHG estimates gives the quantitative effect of labor supply changes during the pandemic, while the difference between baseline and counterfactual potential work hours gives the change in labor supply independent of compositional changes in the labor market during the pandemic.

Figure 6 shows the results of our counterfactual exercise. The top panel shows our baseline and counterfactual estimates of the AHG compared to the unemployment rate, while the bottom panel shows our baseline and counterfactual estimates of potential hours compared to the labor force participation rate. The figure shows that ignoring the fall in desired work hours during the pandemic implies a higher AHG estimate, and therefore a higher level of underutilization. By the end of 2021, the level of underutilization implied by the counterfactual AHG is also substantially higher than the unemployment rate. Quantitatively, the counterfactual AHG implies a degree of labor market underutilization that is 2.5 percentage points (12.5 percent) higher than the level implied by the baseline AHG in December 2021.

The bottom panel of Figure 6 shows that ignoring the fall in desired work hours accounts for essentially all of the difference in declines between the baseline estimate of potential work hours and the labor force participation rate. Our counterfactual potential hours series essentially lies on top of the labor force participation rate before and during the pandemic. Together with our baseline estimates of potential hours, the results imply that labor supply fell by about twice as much as the labor force participation rate during the pandemic (and remains depressed), and all of the discrepancy between the two measures reflects a reduction in desired work hours throughout the labor market. 
Figure 7 and Table 2 highlight the sources of the differences between our baseline and counterfactual AHG estimates by labor force status. Figure 7 plots the contributions of the employed, unemployed, and those out of the labor force to the baseline and counterfactual AHG measures. The figure shows that most of the difference between the two estimates (and most of the decline in desired work hours) occurs among those who are out of the labor force. There is also a smaller but notable contribution by the employed. The unemployed contribute essentially nothing to the difference between our baseline and counterfactual estimates, reflecting the consistency of their desired work hours we observe in Table 1.

Table 2 breaks out the differences in what the baseline and counterfactual AHG estimates imply about underutilization during the pandemic. It reports the (baseline) AHG and the contribution of detailed labor force states in February 2020, just before the start of the pandemic, and the change of each between then and December 2021 under the baseline and counterfactual estimates. Overall, the baseline AHG is nearly 0.5 percentage points below its February 2020 level, while the counterfactual AHG is 2.0 percentage points above the February 2020 level. These combine to produce the 2.5 percentage point difference highlighted earlier. Table 2 shows that the bulk of this difference is accounted for by part-time workers and those out of the labor force but do not want work. Part-time workers contribute 0.5 percentage points to the overall difference; the retired contribute 0.4 percentage points, and those out of the labor force for other reasons contribute 1.7 percentage points. Full-time workers actually have a slightly lower hours gap in the counterfactual case and therefore reduce the gap between the baseline and counterfactual AHG by 0.2 percentage points. All of these contributions are consistent with the main drivers of the decline in desired work hours reported in Table 1. 
Finally, Table 3 reports the differences between the baseline and counterfactual AHG and potential work hours estimates by gender, age, and education. The table shows that, under the baseline estimates, most demographic groups are near or at their February 2020 levels of underutilization, with men and the college-educated considerably below their February 2020 levels, by December 2021. Older individuals and those with less than a college degree have the largest differences between their baseline and counterfactual AHG estimates.

\subsection{Evidence on the Role of Covid}

Next, we examine evidence on the extent that Covid is directly related to the observed decline in desired work hours. We start by estimating the change in desired work hours by the type of job individuals currently or most recently worked at. We group job types by the degree of social contact required of the job, since higher degrees of social contact imply a higher potential exposure to Covid. Specifically, we calculate an effective social proximity index for all two-digit occupations and major industry sectors. Our index is the social proximity index for each of these occupations and industries developed by Leibovici, Santacreu, and Famiglietti (2020) multiplied by one minus the share of individuals who can work from home estimated by Dingel and Neiman (2020). The index derived by Leibovici et al. assigns occupations an index value based on the tasks required of the job in their $\mathrm{O}^{*} \mathrm{NET}$ job description. For industries, the index is based on the occupational mix of that industry. We group occupations and industries into (roughly employmentweighted) thirds based on their effective proximity index value. ${ }^{18}$

\footnotetext{
18 The occupations with the highest effective social proximity include healthcare professionals, food preparation workers, and those in production, construction, transportation, and personal care services. The occupations with the lowest effective social proximity include managers, technical professionals, legal professionals and those in education. The industries with the highest effective social proximity are health services, leisure and hospitality, retail, construction, resources, and transportation and warehousing. The industries with the lowest effective social proximity are professional and business services, financial activities, government, information, wholesale, and education.
} 
Table 4 presents our results. We find that individuals who currently or recently worked in occupations and industries with at least a relatively moderate degree of social contact desired to work fewer hours during the Covid pandemic. Those in the middle and high social proximity groups exhibited a decline in desired work hours between 0.8 and 4.0 hours ( 3 and 12 percent). In contrast, those in occupations and industries with the lowest degree of social contact actually desired to work more hours during the pandemic, reporting increases between 0.3 and 1.3 hours ( 1 and 4 percent). Thus, the evidence based on potential Covid exposure at one's job is consistent with Covid playing a role in the observed decline in labor supply.

Table 5 presents a sort of consistency check on the notion that the decline in desired work hours reflects a reduction in labor supply. It reports the $(\log )$ level and change over time of real hourly reservation wages reported by individuals in the SCE Job Search Supplement. In general, a rise in the average reservation wage across individuals should accompany any contraction in labor supply. Issues related to the pandemic should also cause an increase in reservation wages. These include the higher health risk of potentially contracting Covid and higher opportunity costs of work because of increased family responsibilities at home. Table 5 shows that this is indeed supported by the data. Reservation wages across all individuals rose a statistically significant $6 \log$ points (6.2 percent) during the pandemic. The employed and those out of the labor force each had an increase over $7 \log$ points, and all reported demographic groups show an increase in their reservation wages as well. The largest increases were for men, prime-age workers, and lesseducated workers. Only the unemployed report a decline in the reservation wage.

In general, a reduction in job search effort may accompany a contraction in labor supply. Both the CPS and the SCE Job Search Supplement allow us to go a step further and examine the direct role of Covid in reducing search effort. Starting in May 2020, the CPS began asking 
respondents who were out of the labor force if they did not look for work because of Covid. In its 2020 and 2021 surveys, the SCE supplement follows up with preexisting questions on why individuals (regardless of labor force status) did not search or only searched for part-time work to see if their search behavior was due to the Covid pandemic.

Figure 8 shows the time series behavior of the share of those out of the labor force in the CPS that report not looking for work because of Covid. It reports the share for all of those out of the labor force and for the subset that report "wanting work." The figure shows that over 9 percent of those out of the labor force, and 56 percent of those who "want work" reported Covid as the reason they were not looking for work in May of 2020. The shares fall to about 4 percent and 25 percent, respectively, by October 2020, and are much lower, at 1 percent 7 percent, respectively, by the end of 2021. The estimates line up well to the responses from the SCE supplement, which shows that 9 percent of the nonemployed did not search due to Covid in October 2020, with the share falling to just over 1 percent in October 2021. The SCE supplement provides additional statistics that show a broader, but generally consistent view of the effect of Covid on search behavior. Across all individuals, 4 percent report not looking for work because of Covid in October 2020 and this share falls to 1 percent in October 2021. Fear of contracting the virus and a perceived lack of job opportunities are the main reasons respondents cite in 2020 , while fear of catching the virus remains as the most notable reason for not looking in 2021. Covid is much less likely to reduce on-the-job search among the employed. Across demographic categories, Covid is more likely to affect the incidence of job search for women, older workers, and those with less than a college degree. Covid had quantitatively similar effects on the incidence of searching only for parttime work (conditional on actively looking for work). Across all respondents, 9 percent of job seekers report looking for only part-time work because of Covid in October 2020. This falls to 2 
percent in October 2021. The share is highest in 2020 for women, prime-age workers, and those with less than a college degree. Notably, it is similar for both the employed and nonemployed, and remains relatively elevated for the nonemployed and for women into 2021.

Finally, Table 7 reports measures of job search effort over time from the SCE Job Search Supplement. We report the 2020 and 2021 estimates separately from average estimates for 201317 and 2018-19. In general, our measures of search effort show a decline in search in 2020 followed by a rebound in 2021. Keep in mind that the October 2020 survey occurs six months after the worst of the Covid pandemic's effects on the labor market, so the decline in search effort may have been much larger early on. ${ }^{19}$ The number of applications sent in the prior four weeks falls then rebounds across all labor force states (employed, unemployed, and out of the labor force). The incidence of on-the-job search falls and then recovers as well.

Overall, the evidence on job search behavior paints a mixed picture of the effects of Covid on job search effort. The results show that Covid clearly had a large impact on search effort, and ultimately, the willingness to work, in the first months of the pandemic. In 2021, however, the share of individuals citing Covid as a reason for not looking for work declined precipitously. Despite this, we observe no recovery in desired work hours or the labor force participation rate. Several reasons may account for the divergence of labor supply and job search toward the end of 2021. The tightening of the labor market likely improved the returns to job search while lingering concerns about health and issues related to child and dependent care may have kept labor supply depressed. For example, we find that 36 percent of household children still had their schooling affected by Covid in 2021, which may affect the work decisions of their parents. The Covid pandemic may have also permanently changed the attitudes toward work. Some individuals may

\footnotetext{
${ }^{19}$ Forsythe et al. (2020) and Marinescu, Skandalis, and Zhou (2021) present richer evidence on search behavior during the early months of the pandemic.
} 
have become accustomed to a greater degree of work flexibility, including working from home, while others may now prefer a greater degree of work-life balance. ${ }^{20}$ Others still may now prefer a change in career towards something that provides different wages, hours, and benefits than what they previously had. From this perspective, it will be of great interest to follow the evolution of desired work hours in the SCE in the coming years.

\section{Conclusions}

In this paper, we analyze labor market underutilization and labor supply behavior of workers during the Covid pandemic, building on the Aggregate Hours Gap developed by Faberman, Mueller, SSahin, and Topa (2020). We find diverging patterns between the AHG and the unemployment rate, though the nature of the divergence is not the same during the Covid pandemic as it was following the Great Recession. The Covid pandemic is characterized by a relatively tight labor market, with the AHG already below its February 2020 level by the end of 2021. We find that this is driven by individuals out of the labor force and part-time workers whose desired work hours dropped substantially during the Covid pandemic. The decline in desired work hours is more than double the decline in the labor force participation rate and is just as persistent throughout the pandemic. We perform a counterfactual exercise that holds desired work hours constant at their pre-pandemic average within detailed labor force and demographic groups and recalculates the AHG and associated potential work hours from March 2020 forward. We find that the decline in desired work hours reduced the AHG by 2.5 percentage points (12.5 percent) relative to its estimated value at the end of 2021, and it accounts for essentially all of the discrepancy between potential work hours and the labor force participation rate. Our evidence does not support the

\footnotetext{
${ }^{20}$ Barreo, Bloom, and Davis (2021) argue that an increase in the share of individuals working from home is likely a permanent structural change in the labor market.
} 
notion that the contraction in labor supply is driven mostly by women responding to child care demands. Instead, the drop in desired hours is pervasive across most demographic groups, with somewhat larger declines among those with less than a college degree. The decline is also concentrated among what we refer to as the intensive margin of labor force participation. This margin represents individuals who prefer to work infrequently, and when they do, they generally prefer part-time work hours.

Finally, we find a range of suggestive evidence that shows that the Covid pandemic likely plays a considerable role in the observed reduction in desired work hours — including lower desired hours among those in jobs with a higher potential exposure to Covid—but that its effects on job search behavior mostly dissipate by the end of 2021 . We also find that most individuals have persistently higher reservation wages throughout the pandemic, consistent with a reassessment of their labor supply decisions. Our findings suggest that an overall lower willingness to work has led to a contraction in labor supply that persists throughout the Covid pandemic. This decline contributed to the rapid tightening of the labor market following the onset of the pandemic.

Our results also demonstrate the value of collecting survey data on desired work hours that are consistently fielded over time. Adopting such a question in household surveys such as the Current Population Survey would allow researchers and policymakers to assess the role of the intensive margin of aggregate labor supply in future downturns using larger samples and with greater detail than currently possible in the SCE. 


\section{References}

Alon, Titan, Matthias Doepke, Jane Olmstead-Rumsey, and Michèle Tertilt, 2020. "This Time It's Different: The Role of Women's Employment in a Pandemic Recession," NBER Working Paper No. w27660.

Atkinson, Tyler, Jim Dolmas, Marc Giannoni, Robert S. Kaplan, and Karel Mertens, 2021. "The Labor Market May Be Tighter than the Level of Employment Suggests." Dallas Fed Economics blog.

Barnichon, Regis, and Andrew Figura, 2016. "Declining Desire to Work and Downward Trends in Unemployment and Participation." NBER Macroeconomics Annual 30(1): 449-494.

Barnichon, Regis, and Winnie Yee, 2020. “Adjusting the Unemployment Thermometer.” Federal Reserve Bank of San Francisco Economic Letter, 2020-27.

Barrero, Jose Maria, Nicholas Bloom, and Steven J. Davis, 2021. "Why Working from Home Will Stick," NBER Working Paper No. w28731.

Bartik, Alexander W., Marianne Bertrand, Feng Lin, Jesse Rothstein, and Matthew Unrath, 2020. "Measuring the Labor Market at the Onset of the COVID-19 Crisis." Brookings Papers on Economic Activity, No. 2: 239-268.

Bick, Alexander, and Andrew Blandin, 2021. "Real-Time Labor Market Estimates During the 2020 Coronavirus Outbreak.” Arizona State University, mimeo.

Cajner, Tomaz, Leland D. Crane, Ryan A. Decker, John Grigsby, Adrian Hamins-Puertolas, Erik Hurst, Christopher Kurz, and Ahu Yildirmaz, 2020. "The US Labor Market during the Beginning of the Pandemic Recession." Brookings Papers on Economic Activity: 3-34.

Crump, Richard K., Stefano Euseppi, Marc Giannoni, and Ayşegül Şahin, 2022. "The Unemployment-Inflation Trade-off Revisited: The Phillips Curve in COVID Times,” mimeo.

Dingel, Jonathan I. and Brent Neiman, 2020. "How Many Jobs can be done at Home?" Journal of Public Economics 189: 104325.

Domash, Alex, and Lawrence H. Summers, 2022. "How Tight are U.S. Labor Markets?” NBER Working Paper No. 29739.

Faberman, R. Jason, Andreas I. Mueller, Ayşegül Şahin and Giorgio Topa. "Job Search Behavior among the Employed and Non-Employed," forthcoming, Econometrica.

Faberman, R. Jason, Andreas I. Mueller, Ayşegül Şahin and Giorgio Topa, 2020. "The Shadow Margins of Labor Market Slack," Journal of Money, Credit, and Banking, 52(S2), 355-391.

Faberman J. and A. Rajan, 2020. "Is the Unemployment Rate a Good Measure of People Currently Out of Work?" Chicago Fed Insights blog. 
Forsythe, Eliza, Lisa B. Kahn, Fabian Lange, and David Wiczer, 2020. "Searching, Recalls, and Tightness: An Interim Report on the Covid Labor Market," NBER Working Paper No. 28083.

Ganong, Peter, Pascal Noel, and Joseph Vavra, 2020. "US Unemployment Insurance Replacement Rates during the Pandemic." Journal of Public Economics 191: 104273.

Goolsbee, Austan, and Chad Syverson, 2021. "Fear, Lockdown, and Diversion: Comparing Drivers of Pandemic Economic Decline 2020," forthcoming, Journal of Public Economics.

Hobijn, Bart, and Ayşegül Şahin, 2021. "Maximum Employment and the Participation Cycle," NBER Working Paper No. w29222.

Leibovici, Fernando, Ana Maria Santacreu, and Matthew Famiglietti, 2020. "Social Distancing and Contact-Intensive Occupations," On the Economy Blog, Federal Reserve Bank of St. Louis, March 24.

Marinescu, Ioana, Daphne Skandalis, and Daniel Zhao, 2021. "The Impact of the Federal Pandemic Unemployment Compensation on Job Search and Vacancy Creation." Journal of Public Economics 200: 104471.

Mongey, Simon, Laura Pilossoph, and Alex Weinberg, 2021. "Which Workers Bear the Burden of Social Distancing Policies?” Journal of Economic Inequality.

Nie, Jun, and Shu-Kuei X. Yang, 2021. "What Has Driven the Recent Increase in Retirements?" Federal Reserve Bank of Kansas City, Economic Bulletin, August 11.

Şahin, Ayşegül, Murat Tasci, and Jin Yan, 2021. "Unemployment in the Time of COVID-19: A Flow-Based Approach to Real-Time Unemployment Projections," NBER Working Paper No. w28445. 
Table 1. Desired Work Hours by Labor Force Status and Demographics

\begin{tabular}{|c|c|c|c|c|}
\hline October of... & 2013-17 & 2018-19 & 2020-21 & $\begin{array}{c}\text { Difference, } \\
\text { '20-21 - '18-19 }\end{array}$ \\
\hline \multicolumn{5}{|l|}{ Labor Force Status } \\
\hline Employed & 41.54 & 41.69 & 41.10 & -0.59 \\
\hline \multirow{2}{*}{ Full-time } & 44.88 & $\begin{array}{l}(0.31) \\
45.11\end{array}$ & $\begin{array}{l}(0.54) \\
45.11\end{array}$ & $\begin{array}{l}(0.4 /) \\
-0.00\end{array}$ \\
\hline & $(0.16)$ & $(0.25)$ & $(0.26)$ & $(0.45)$ \\
\hline \multirow{2}{*}{ Part-time } & 28.68 & 27.10 & 23.97 & -3.13 \\
\hline & $(0.49)$ & $(0.82)$ & $(0.72)$ & $(0.93)$ \\
\hline \multirow{2}{*}{ Unemployed } & 35.62 & 36.07 & 35.80 & -0.27 \\
\hline & $(0.70)$ & $(1.53)$ & $(1.01)$ & $(2.30)$ \\
\hline \multirow{2}{*}{ Out of the Labor Force } & 13.06 & 12.01 & 11.06 & -0.94 \\
\hline & $(0.33)$ & $(0.51)$ & $(0.55)$ & $(0.70)$ \\
\hline \multirow{2}{*}{ Want work } & 29.91 & 30.00 & 27.47 & -2.53 \\
\hline & $(1.86)$ & $(2.74)$ & $(2.09)$ & $(3.14)$ \\
\hline \multirow{2}{*}{ Retired } & 10.99 & 10.25 & 9.68 & -0.57 \\
\hline & $(0.36)$ & $(0.57)$ & $(0.57)$ & $(0.71)$ \\
\hline \multirow{2}{*}{ Others out of the labor force } & 15.45 & 14.46 & 11.17 & -3.29 \\
\hline & $(0.65)$ & $(1.02)$ & $(1.22)$ & $(1.02)$ \\
\hline \multicolumn{5}{|l|}{ Gender } \\
\hline \multirow{2}{*}{ Men } & 34.42 & 34.16 & 33.42 & -0.74 \\
\hline & $(0.34)$ & $(0.56)$ & $(0.58)$ & $(0.79)$ \\
\hline \multirow{2}{*}{ Women } & 30.98 & 30.94 & 29.94 & -1.00 \\
\hline & $(0.33)$ & $(0.54)$ & $(0.59)$ & $(0.81)$ \\
\hline \multicolumn{5}{|l|}{ Age } \\
\hline \multirow{2}{*}{ Prime Age (25-54) } & 39.70 & 40.98 & 40.06 & -0.91 \\
\hline & $(0.26)$ & $(0.39)$ & $(0.40)$ & $(0.67)$ \\
\hline \multirow{2}{*}{ Older $(55+)$} & 23.44 & 22.22 & 21.46 & -0.76 \\
\hline & $(0.36)$ & $(0.59)$ & $(0.65)$ & $(0.74)$ \\
\hline \multicolumn{5}{|l|}{ Education } \\
\hline \multirow{2}{*}{ Some college or less } & 30.87 & 31.00 & 29.36 & -1.63 \\
\hline & $(0.35)$ & $(0.60)$ & $(0.67)$ & $(0.70)$ \\
\hline \multirow{2}{*}{ College degree or more } & 36.47 & 35.75 & 35.53 & -0.22 \\
\hline & $(0.31)$ & $(0.49)$ & $(0.49)$ & $(0.94)$ \\
\hline
\end{tabular}

Notes: Table reports mean desired work hours for each labor force state or demographic group. Estimates are for respondents in each category pooled across SCE surveys within each listed time period, and desired hours are adjusted to impose a zero-minimum desired hours gap among the employed. The last column reports the difference between the 2018-19 mean and the 2020-21 mean for each category. Standard errors are in parentheses. 
Table 2. Baseline vs. Counterfactual Changes in the AHG by Labor Force Status

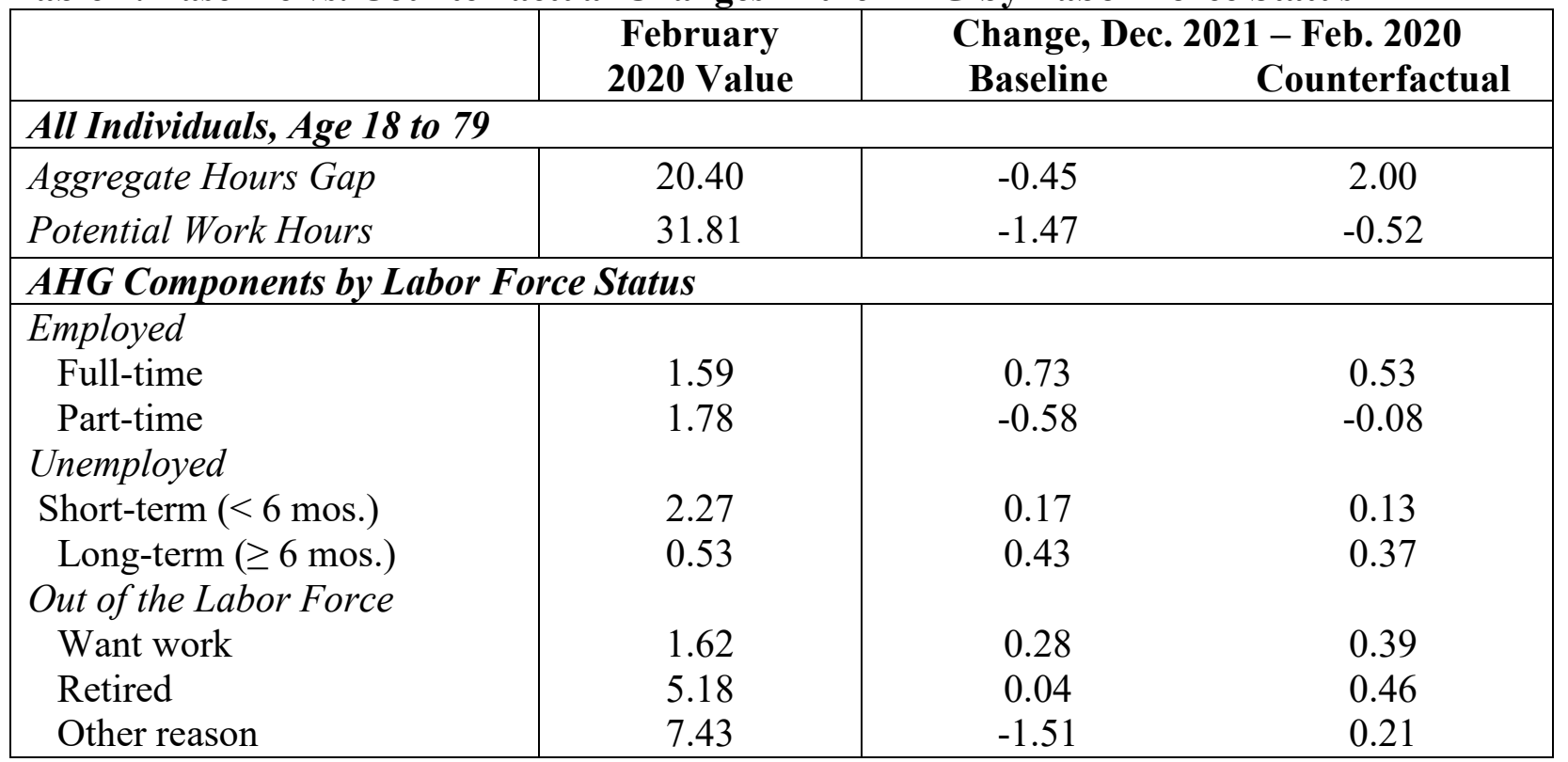

Notes: Estimates are from authors' calculations using CPS and SCE data for all individuals age 18 to 79. Baseline and counterfactual estimates of the AHG and potential work hours replicate those from Figure 6, with the AHG broken out by detailed labor force state. Counterfactual estimates recalculate each series holding desired hours constant within each labor force status $\times$ demographic estimation cell from March 2020 forward. See text for details.

Table 3. Baseline vs. Counterfactual Changes in the AHG by Demographics

\begin{tabular}{|l|c|cc|}
\hline \multicolumn{2}{|l|}{} & $\begin{array}{c}\text { February } \\
\text { 2020 Value }\end{array}$ & $\begin{array}{c}\text { Change, Dec. 2021 - Feb. 2020 } \\
\text { Baseline }\end{array}$ \\
\hline \multicolumn{3}{|l|}{ Counterfactual } \\
\hline Gender & & & 1.75 \\
\hline Men & 17.33 & -0.57 & 2.28 \\
Women & 23.89 & -0.17 & 1.95 \\
\hline Age & & & 2.59 \\
\hline Prime Age (25-54) & 13.46 & 0.31 & 2.59 \\
Older (55+) & 30.95 & -0.12 & 1.24 \\
\hline Education & & & 0.03 \\
\hline Some college or less & 24.36 & -0.91 & \\
College or more & 13.84 &
\end{tabular}

Notes: Estimates are from authors' calculations using CPS and SCE data for all individuals age 18 to 79 . Baseline and counterfactual estimates of the AHG replicate those from Figure 6, with the AHG broken out by demographic group. Counterfactual estimates recalculate each series holding desired hours constant within each labor force status $\times$ demographic estimation cell from March 2020 forward. See text for details. 
Table 4. Desired Work Hours by Social Proximity Required of Occupation or Industry

\begin{tabular}{|l|ccc|c|}
\hline \multicolumn{1}{|c|}{ October of... } & $\mathbf{2 0 1 3 - 1 7}$ & $\mathbf{2 0 1 8 - 1 9}$ & $\mathbf{2 0 2 0 - 2 1}$ & $\begin{array}{c}\text { Difference, } \\
\text { '20-21 - '18-19 }\end{array}$ \\
\hline Prior Month's Occupation & & & & \\
\hline Low Social Proximity & 36.04 & 35.05 & 36.32 & 1.27 \\
& $(0.37)$ & $(0.62)$ & $(0.62)$ & $(1.01)$ \\
Medium Social Proximity & 31.90 & 33.56 & 29.51 & -4.04 \\
& $(0.41)$ & $(0.69)$ & $(0.76)$ & $(1.08)$ \\
High Social Proximity & 32.38 & 32.19 & 31.36 & -0.83 \\
\hline Prior Month's Industry & $(0.49)$ & $(0.80)$ & $(0.89)$ & $(1.03)$ \\
\hline \multirow{2}{*}{ Low Social Proximity } & & & & \\
Medium Social Proximity & 31.95 & 31.16 & 31.43 & 0.28 \\
& $(0.38)$ & $(0.61)$ & $(0.60)$ & $(0.91)$ \\
High Social Proximity & 33.85 & 34.52 & 32.20 & -2.32 \\
& $(0.45)$ & $(0.73)$ & $(0.85)$ & $(1.13)$ \\
& 33.34 & 33.37 & 32.50 & -0.86 \\
& $(0.41)$ & $(0.71)$ & $(0.75)$ & $(0.96)$ \\
\hline
\end{tabular}

Notes: Table reports mean desired work hours for each occupation or industry group. Estimates are for respondents in each category pooled across SCE surveys within each listed time period, and desired hours are adjusted to impose a zero-minimum desired hours gap among the employed. The last column reports the difference between the 2018-19 mean and the 2020-21 mean for each category. Social proximity is defined by the degree of interpersonal contact and the ability to work from home for the respondent's current or most recent job. See text for details of the identification. Standard errors are in parentheses. 
Table 5. Real Reservation Wages by Labor Force Status, Demographics, and Job Type

\begin{tabular}{|c|c|c|c|c|}
\hline October of... & 2013-17 & 2018-19 & 2020-21 & $\begin{array}{c}\text { Difference, } \\
\text { '20-21 - '18-19 }\end{array}$ \\
\hline \multicolumn{5}{|c|}{ Real Reservation Wage (log hourly wage, 2019 dollars) } \\
\hline All Individuals & $\begin{array}{c}3.034 \\
(0.010)\end{array}$ & $\begin{array}{c}3.092 \\
(0.017)\end{array}$ & $\begin{array}{c}3.153 \\
(0.019)\end{array}$ & $\begin{array}{c}0.060 \\
(0.025)\end{array}$ \\
\hline \multicolumn{5}{|l|}{ Labor Force Status } \\
\hline Employed & $\begin{array}{c}3.156 \\
(0.012)\end{array}$ & $\begin{array}{c}3.210 \\
(0.019)\end{array}$ & $\begin{array}{c}3.281 \\
(0.021)\end{array}$ & $\begin{array}{c}0.071 \\
(0.028)\end{array}$ \\
\hline Unemployed & $\begin{array}{c}2.634 \\
(0.032)\end{array}$ & $\begin{array}{c}2.840 \\
(0.106)\end{array}$ & $\begin{array}{c}2.759 \\
(0.078)\end{array}$ & $\begin{array}{l}-0.081 \\
(0.110)\end{array}$ \\
\hline Out of the labor force & $\begin{array}{c}2.773 \\
(0.019)\end{array}$ & $\begin{array}{c}2.778 \\
(0.028)\end{array}$ & $\begin{array}{c}2.854 \\
(0.037)\end{array}$ & $\begin{array}{c}0.076 \\
(0.049)\end{array}$ \\
\hline \multicolumn{5}{|l|}{ Gender } \\
\hline $\begin{array}{l}\text { Men } \\
\text { Women }\end{array}$ & $\begin{array}{c}3.226 \\
(0.015) \\
2.868 \\
(0.013) \\
\end{array}$ & $\begin{array}{c}3.231 \\
(0.025) \\
2.951 \\
(0.021) \\
\end{array}$ & $\begin{array}{c}3.307 \\
(0.027) \\
3.007 \\
(0.025) \\
\end{array}$ & $\begin{array}{c}0.076 \\
(0.035) \\
0.055 \\
(0.034) \\
\end{array}$ \\
\hline \multicolumn{5}{|l|}{ Age } \\
\hline $\begin{array}{l}\text { Prime Age (25-54) } \\
\text { Older }(55+)\end{array}$ & $\begin{array}{c}3.116 \\
(0.013) \\
2.918 \\
(0.015) \\
\end{array}$ & $\begin{array}{c}3.174 \\
(0.022) \\
2.982 \\
(0.025) \\
\end{array}$ & $\begin{array}{c}3.248 \\
(0.023) \\
2.998 \\
(0.031) \\
\end{array}$ & $\begin{array}{c}0.075 \\
(0.031) \\
0.016 \\
(0.042) \\
\end{array}$ \\
\hline \multicolumn{5}{|l|}{ Education } \\
\hline $\begin{array}{l}\text { Some college or less } \\
\text { College or more }\end{array}$ & $\begin{array}{c}2.842 \\
(0.013) \\
3.424 \\
(0.014) \\
\end{array}$ & $\begin{array}{c}2.873 \\
(0.022) \\
3.471 \\
(0.022) \\
\end{array}$ & $\begin{array}{c}2.927 \\
(0.026) \\
3.489 \\
(0.023) \\
\end{array}$ & $\begin{array}{c}0.053 \\
(0.029) \\
0.018 \\
(0.036) \\
\end{array}$ \\
\hline
\end{tabular}

Notes: Table reports estimates of the log real hourly reservation wage by selected labor force and demographic characteristics. Estimates are for respondents age 18 to 79 in each category pooled across SCE surveys within each listed time period. Standard errors are in parentheses. 
Table 6. Effects of the Covid Pandemic on Search Behavior

\begin{tabular}{|c|c|c|c|c|}
\hline \multirow[b]{2}{*}{ October of... } & \multicolumn{2}{|c|}{$\begin{array}{l}\text { Pct. Only Searched Part-Time } \\
\text { due to Covid, Cond. on Search }\end{array}$} & \multicolumn{2}{|c|}{$\begin{array}{c}\text { Pct. Did Not Search } \\
\text { Due to Covid }\end{array}$} \\
\hline & 2020 & 2021 & 2020 & 2021 \\
\hline All Individuals & $\begin{array}{l}9.0 \\
(2.4)\end{array}$ & 2.0 & $\begin{array}{l}4.1 \\
(0.6)\end{array}$ & 1.0 \\
\hline Child care/family reasons & 9.0 & 2.0 & 0.7 & 0.2 \\
\hline No work in area & --- & --- & 1.4 & 0.1 \\
\hline Fear of contracting Covid & --- & --- & 2.0 & 0.6 \\
\hline \multicolumn{5}{|l|}{ Labor Force Status } \\
\hline Employed last month & $\begin{array}{l}9.7 \\
(2.9)\end{array}$ & $\begin{array}{c}0.4 \\
(0.5)\end{array}$ & $\begin{array}{c}1.6 \\
(0.5)\end{array}$ & $\begin{array}{c}0.9 \\
(0.3)\end{array}$ \\
\hline Nonemployed last month & $\begin{array}{r}7.9 \\
(4.3) \\
\end{array}$ & $\begin{array}{l}4.7 \\
(2.9) \\
\end{array}$ & $\begin{array}{c}8.9 \\
(1.7)\end{array}$ & $\begin{array}{c}1.2 \\
(0.6) \\
\end{array}$ \\
\hline \multicolumn{5}{|l|}{ Gender } \\
\hline $\begin{array}{l}\text { Men } \\
\text { Women }\end{array}$ & $\begin{array}{l}2.2 \\
(2.0) \\
12.5 \\
(3.5) \\
\end{array}$ & $\begin{array}{c}0.0 \\
(0.0) \\
3.3 \\
(1.7) \\
\end{array}$ & $\begin{array}{l}3.6 \\
(0.9) \\
4.5 \\
(0.9) \\
\end{array}$ & $\begin{array}{c}0.5 \\
(0.3) \\
1.5 \\
(0.5) \\
\end{array}$ \\
\hline \multicolumn{5}{|l|}{ Age } \\
\hline $\begin{array}{l}\text { Prime age }(25-54) \\
\text { Older }(55+)\end{array}$ & $\begin{array}{c}11.4 \\
(3.0) \\
3.4 \\
(0.3)\end{array}$ & $\begin{array}{l}2.1 \\
(1.2) \\
2.1 \\
(2.0)\end{array}$ & $\begin{array}{c}2.9 \\
(0.7) \\
4.5 \\
(1.1)\end{array}$ & $\begin{array}{c}0.8 \\
(0.4) \\
1.2 \\
(0.5)\end{array}$ \\
\hline \multicolumn{5}{|l|}{ Education } \\
\hline $\begin{array}{l}\text { Some college or less } \\
\text { College or more }\end{array}$ & $\begin{array}{c}14.3 \\
(5.0) \\
2.2 \\
(1.5)\end{array}$ & $\begin{array}{c}2.1 \\
(1.6) \\
1.8 \\
(1.2)\end{array}$ & $\begin{array}{c}5.0 \\
(1.1) \\
2.6 \\
(0.7) \\
\end{array}$ & $\begin{array}{c}0.9 \\
(0.4) \\
1.1 \\
(0.4) \\
\end{array}$ \\
\hline
\end{tabular}

Note: The table reports the percentage of individuals who actively looked for work that only searched part-time because of the Covid pandemic, and the percentage of all individuals who did not search for any work because of the Covid pandemic, for each listed group. Estimates come from authors' tabulations from the 2020 and 2021 waves of the SCE Job Search Supplement, for all individuals aged 18-79. Standard errors are in parentheses. 
Table 7. Search Behavior by Labor Force Status

\begin{tabular}{|l|cccc|}
\hline \multicolumn{1}{|c|}{ October of... } & $\mathbf{2 0 1 3 - 1 7}$ & $\mathbf{2 0 1 8 - 1 9}$ & $\mathbf{2 0 2 0}$ & $\mathbf{2 0 2 1}$ \\
\hline Applications Sent in Last 4 Weeks & & & & \\
\hline \multirow{2}{*}{ All Individuals } & 1.12 & 0.85 & 0.76 & 1.25 \\
& $(0.07)$ & $(0.09)$ & $(0.11)$ & $(0.21)$ \\
Employed & 1.03 & 0.76 & 0.69 & 1.11 \\
& $(0.07)$ & $(0.10)$ & $(0.13)$ & $(0.26)$ \\
Unemployed & 9.28 & 8.09 & 6.14 & 10.20 \\
& $(1.06)$ & $(1.49)$ & $(1.03)$ & $(2.52)$ \\
Out of the labor force & 0.27 & 0.29 & 0.13 & 0.29 \\
Percent of Employed Looking in Last 4 Weeks & & & \\
\hline \multirow{2}{*}{ All Employed } & 21.3 & 17.5 & 15.9 & 17.8 \\
& $(0.6)$ & $(1.0)$ & $(1.4)$ & $(1.4)$ \\
\hline
\end{tabular}

Notes: Table reports estimates of search effort by labor force status. Estimates are for respondents age 18 to 79 in each labor force state pooled across SCE surveys within each listed time period. Standard errors are in parentheses. 
Figure 1. The Aggregate Hours Gap vs. the Unemployment Rate

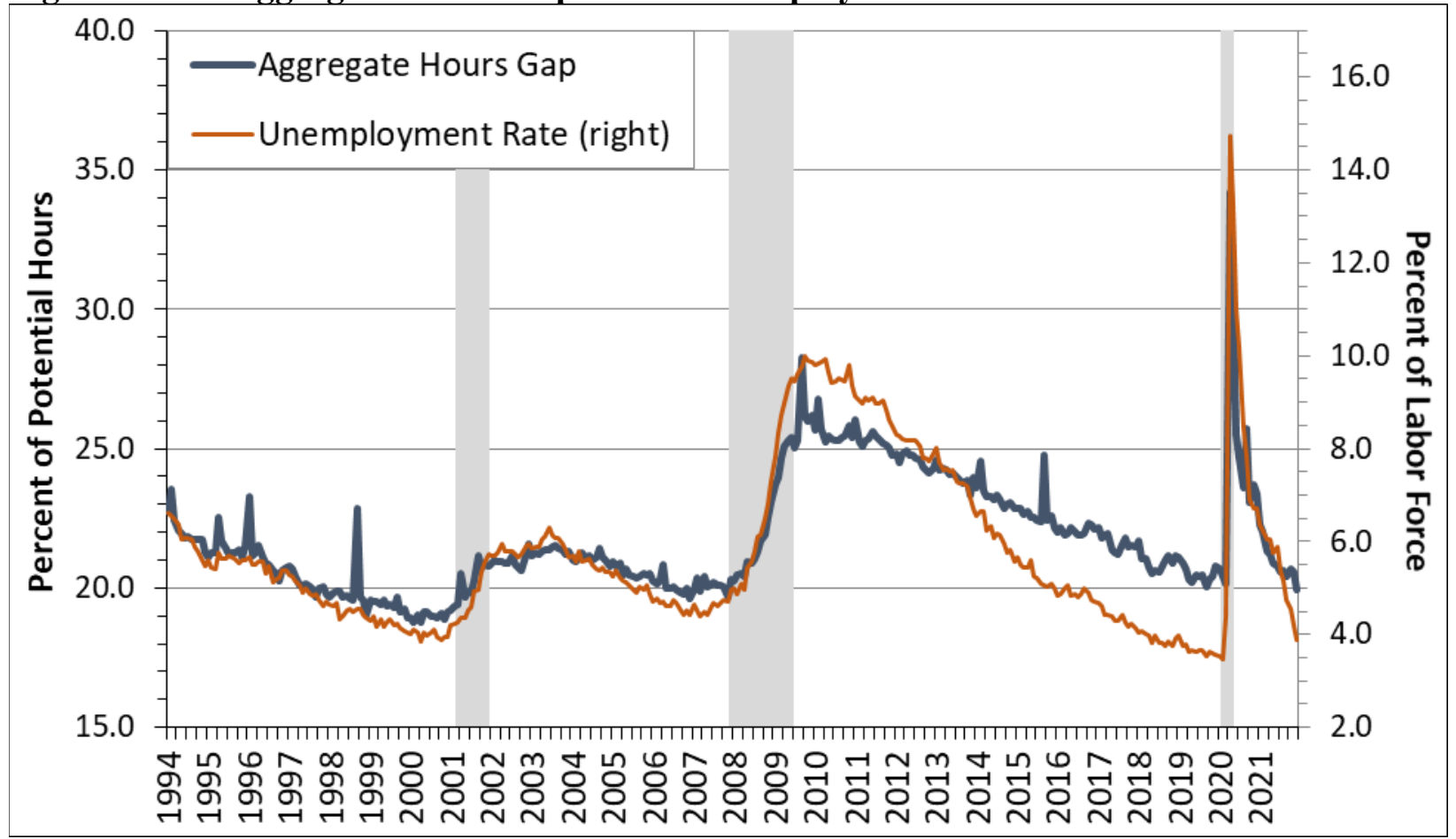

Notes: The Aggregate Hours Gap (AHG) estimates come from authors' calculations using CPS and SCE data for all individuals age 18 to 79 . The unemployment rate uses CPS data. See text for details.

Figure 2. Potential Work Hours vs. the Labor Force Participation Rate

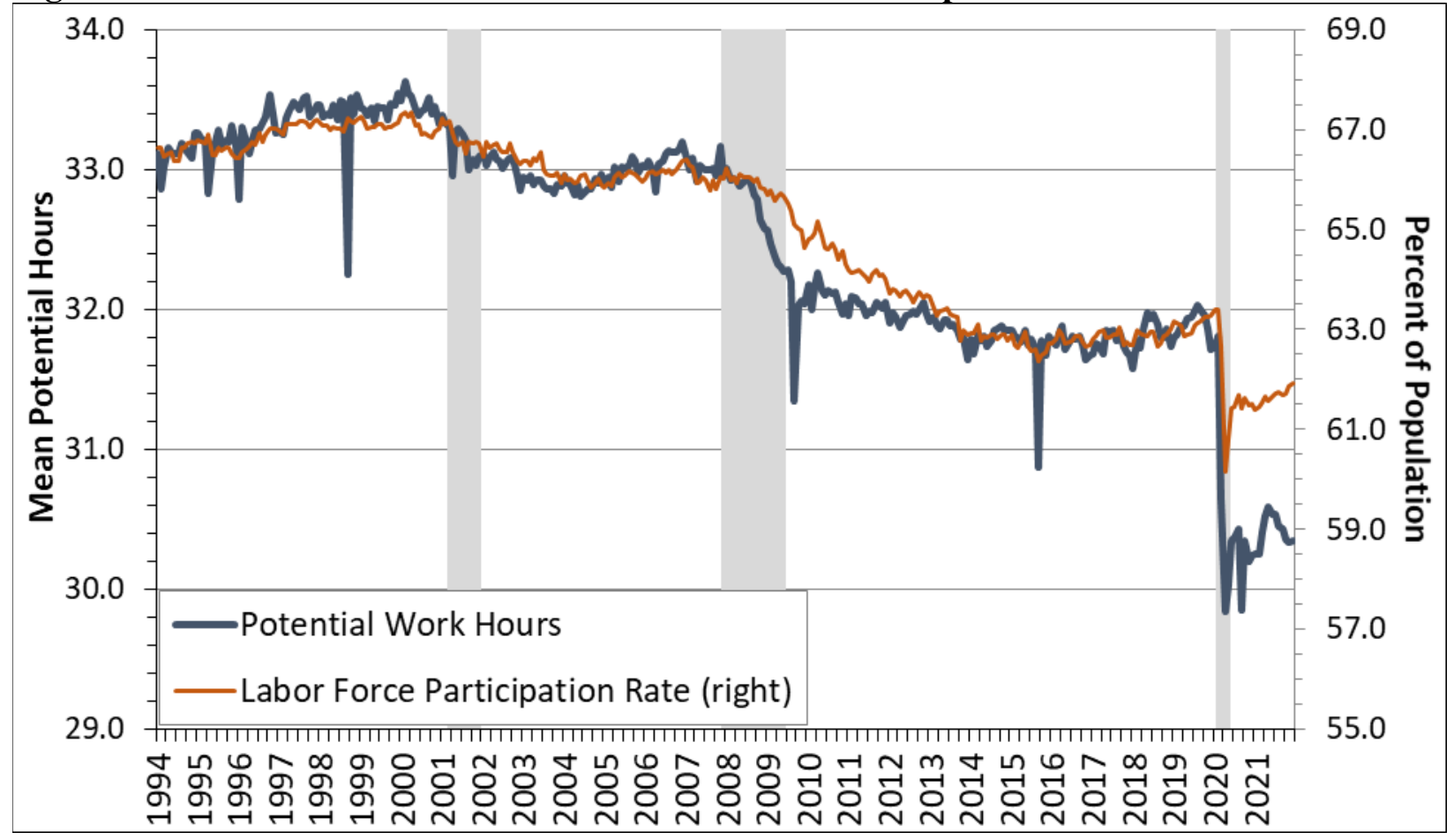

Notes: Potential work hours estimates are from authors' calculations using CPS and SCE data for all individuals age 18 to 79. The labor force participation rate uses CPS data. See text for details. 
Figure 3. The Aggregate Hours Gap vs. the Unemployment Rate, Selected Periods

(a) The Great Recession

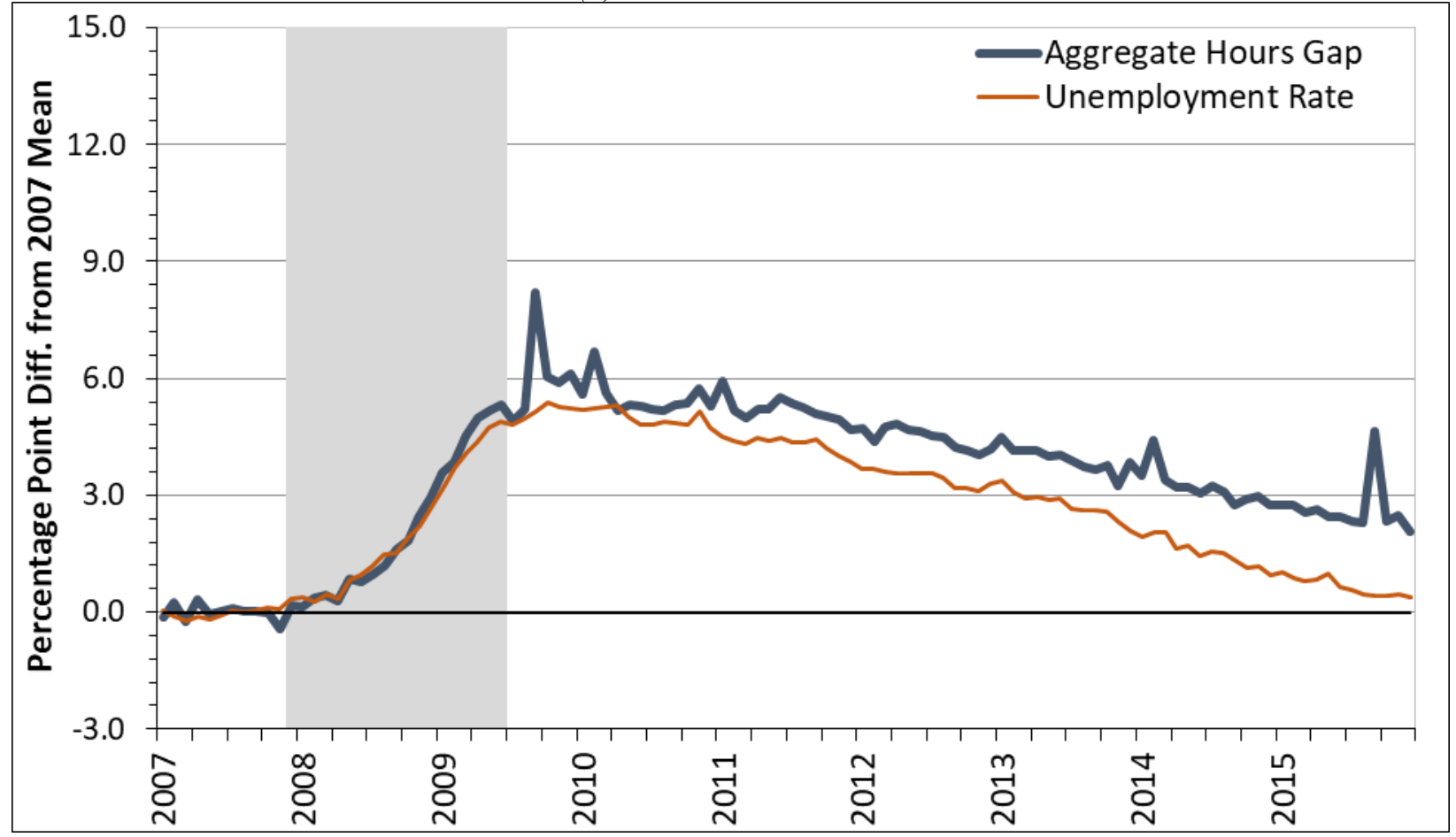

(b) The Covid Pandemic

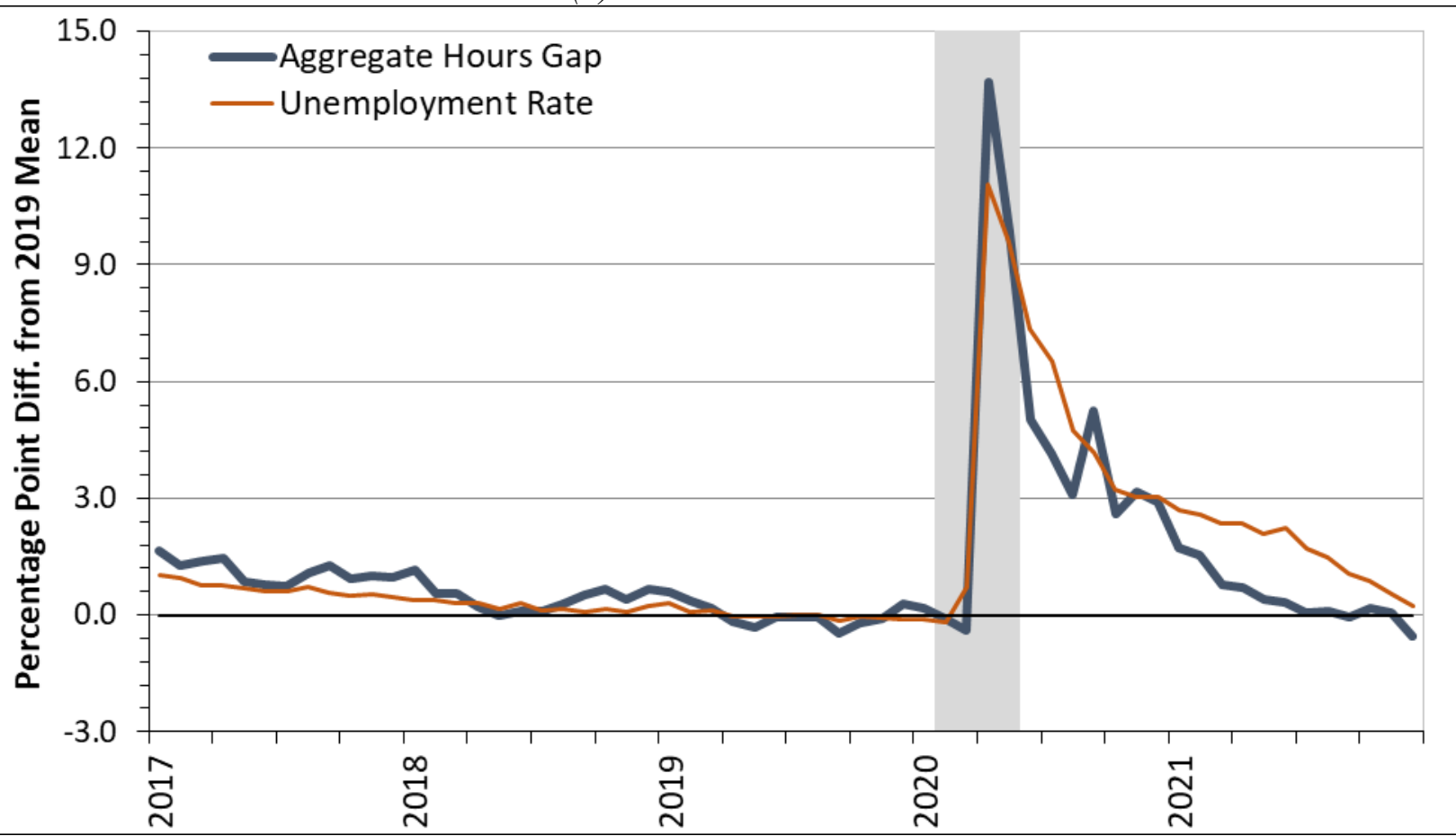

Notes: The Aggregate Hours Gap (AHG) estimates come from authors' calculations using CPS and SCE data for all individuals age 18 to 79. The unemployment rate uses CPS data. The top panel reports each series percentage point deviation from its 2007 average, while the bottom panel reports each series percentage point deviation from its 2019 average. See text for details. 
Figure 4. Components of the Aggregate Hours Gap Over Time

(a) Employment Components, Finer Detail

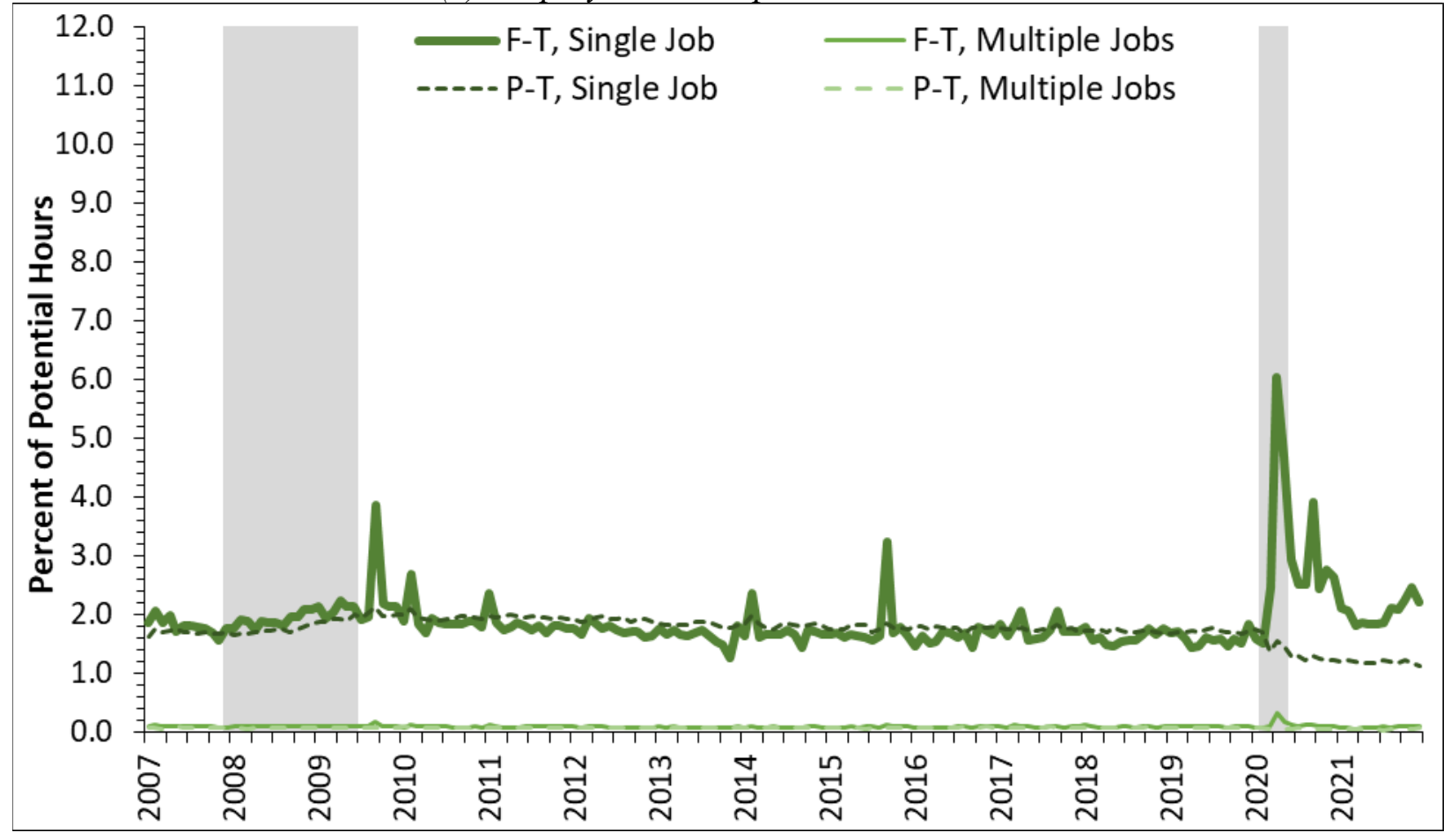

(b) Unemployment Components, Finer Detail

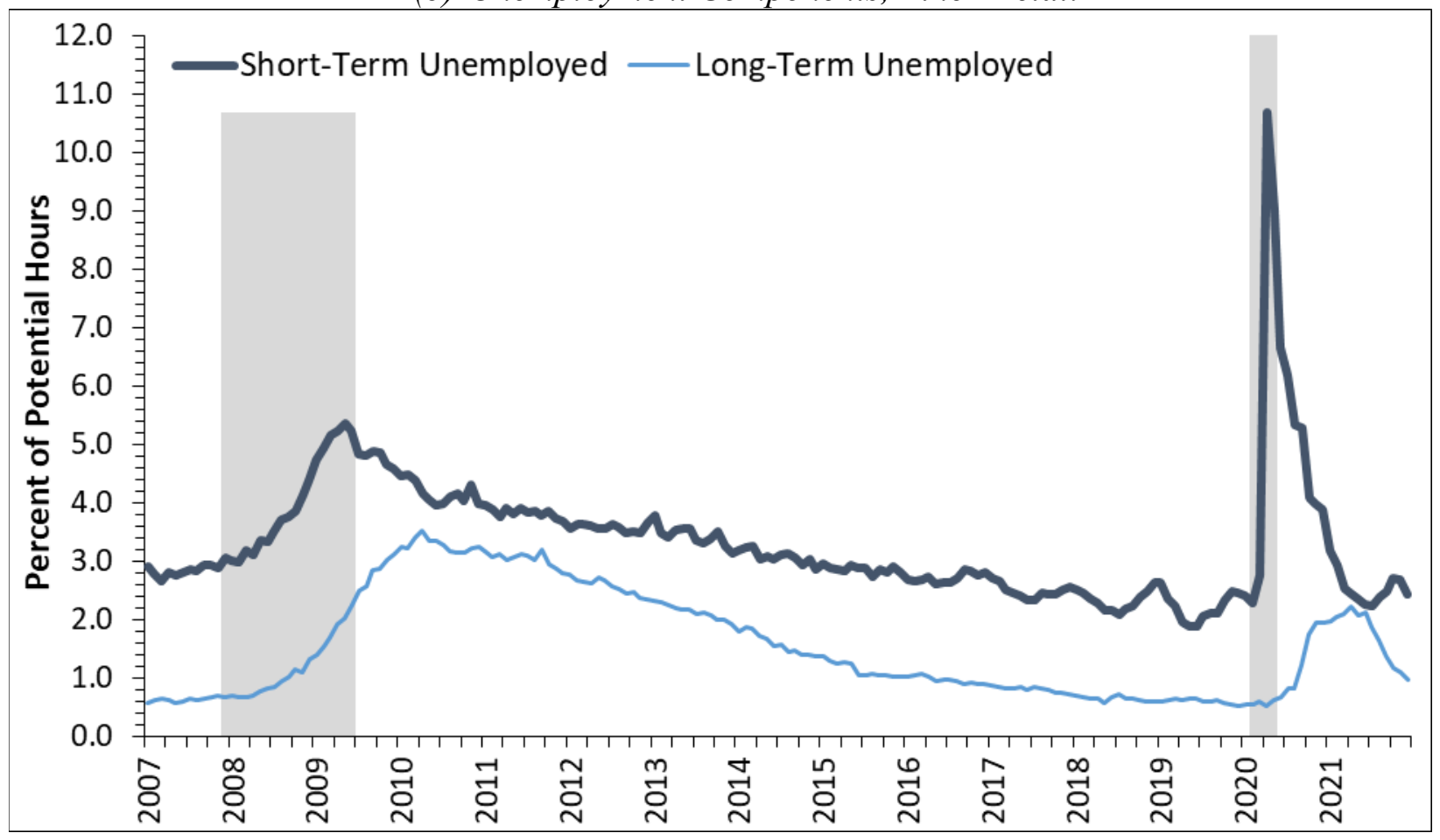


(c) Out of Labor Force Components, Finer Detail

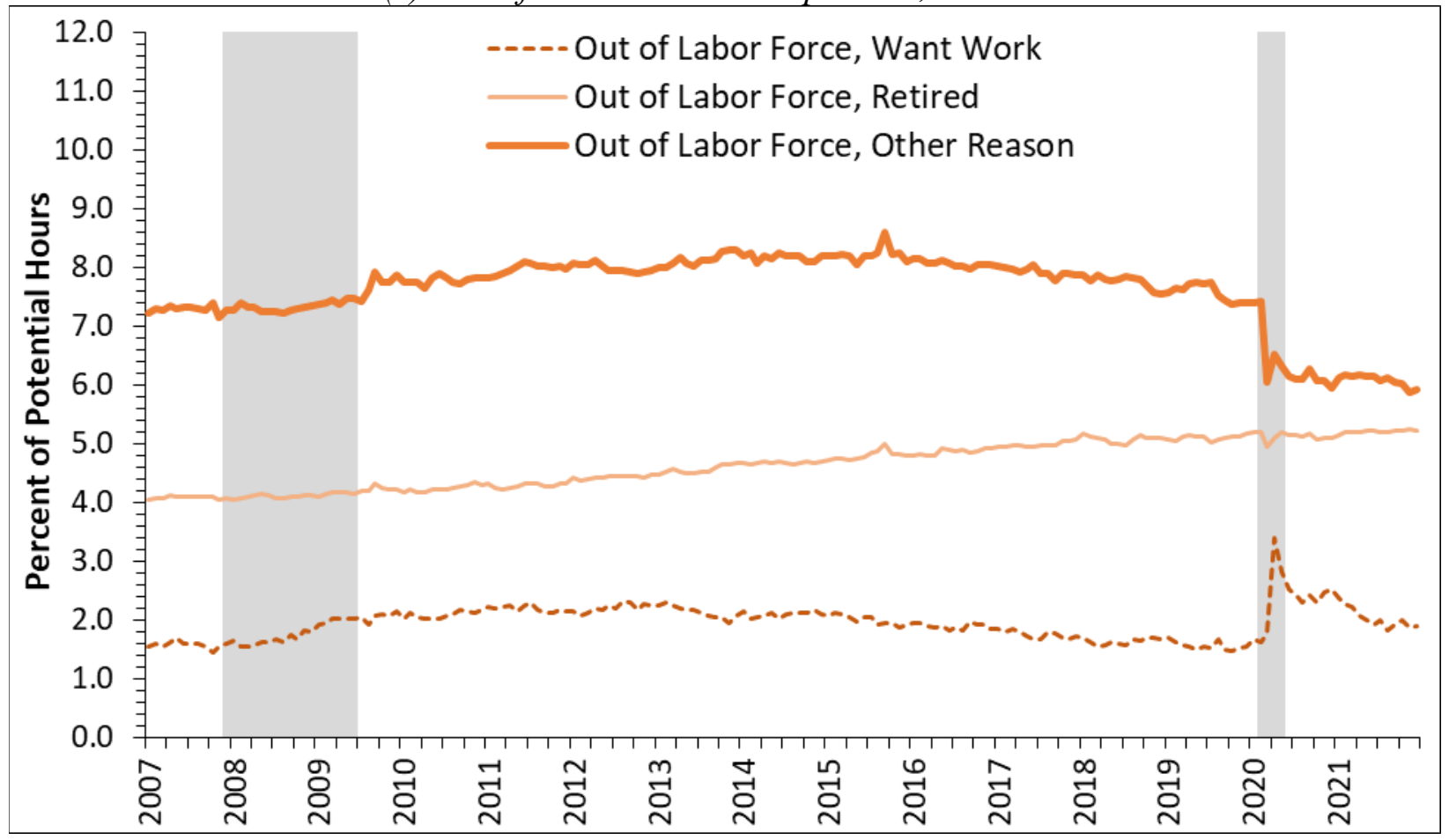

Notes: The Aggregate Hours Gap (AHG) estimates come from authors' calculations using CPS and SCE data for all individuals age 18 to 79. The figure reports the individual AHG components by detailed labor force status. All components are reported as their contribution to the total $\mathrm{AHG}$, as a percentage of mean potential work hours. 
Figure 5. Distribution of Desired Hours and Hours Gaps by Labor Force Status

(a) Hours gap, full-time employed

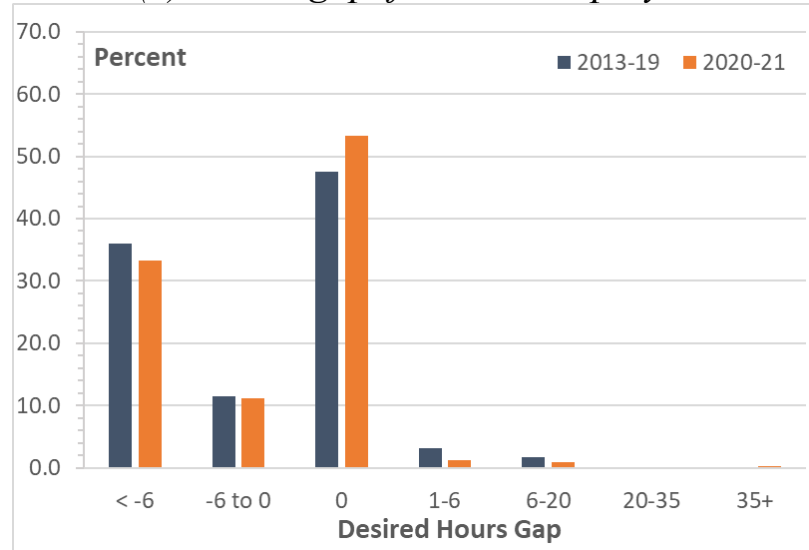

(c) Desired hours, full-time employed

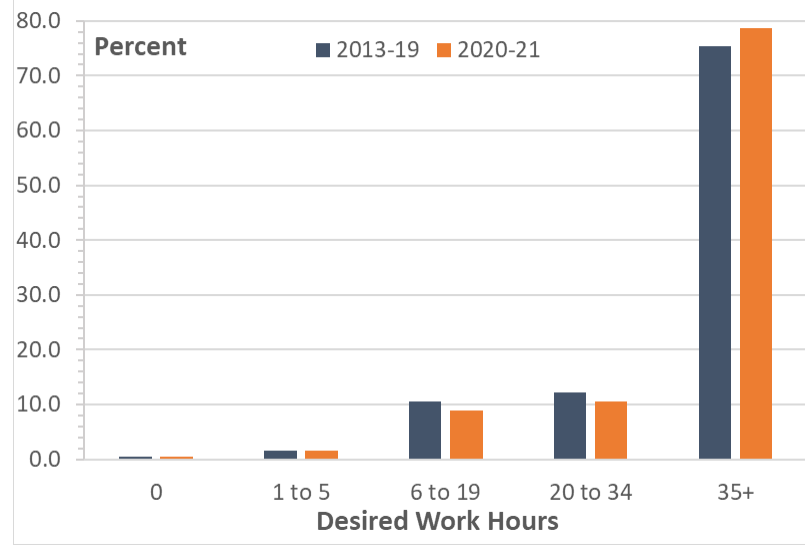

(e) Desired hours, unemployed

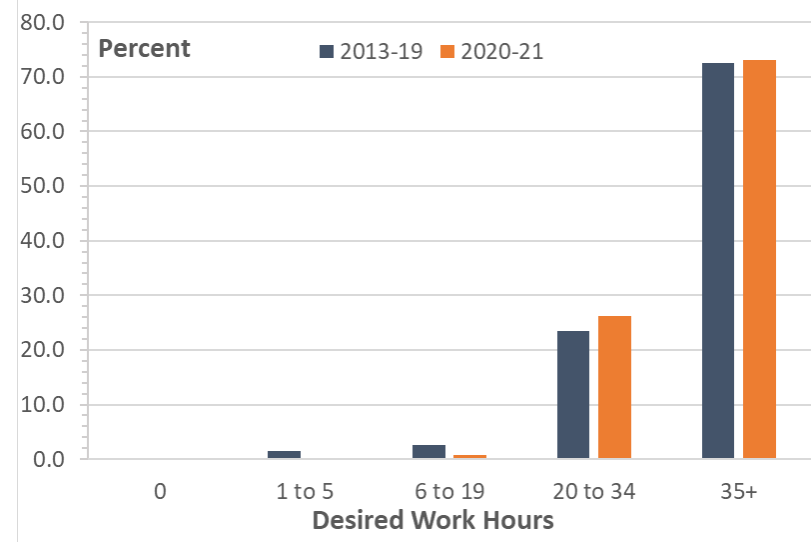

(b) Hours gap, part-time employed

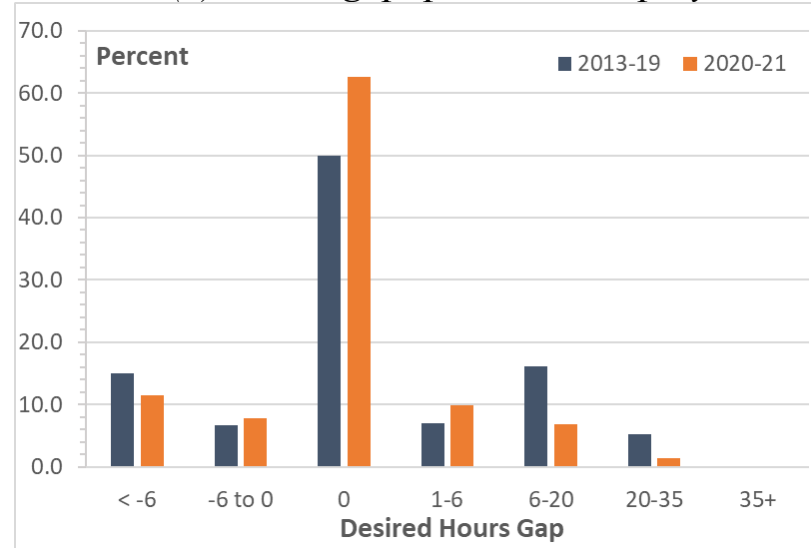

(d) Desired hours, part-time employed

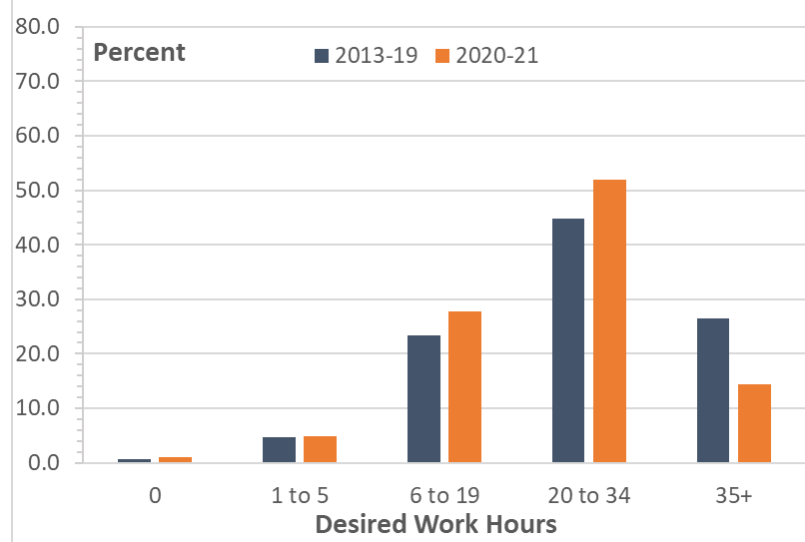

(f) Desired hours, out of the labor force

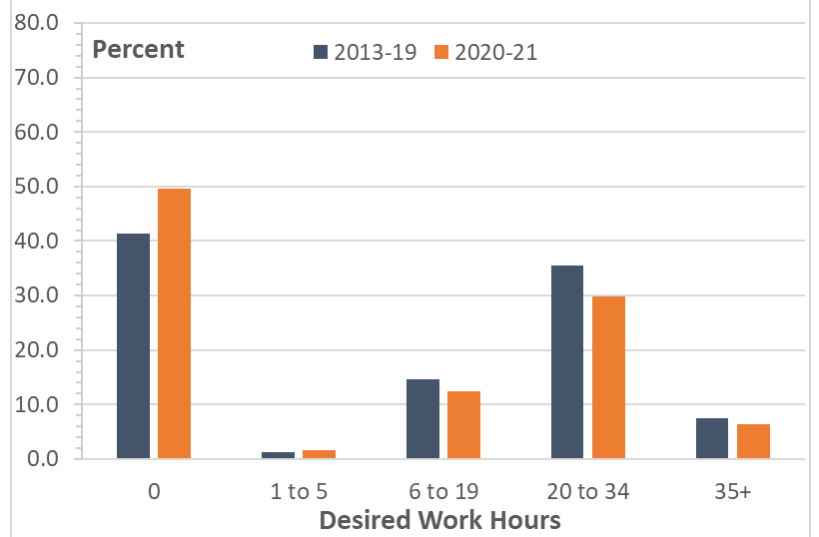

Notes: The top two panels report the distribution of the desired hours gap (desired minus actual work hours) across full-time and part-time workers, respectively. The bottom four panels report the distribution of desired work hours by labor force status. Estimates are from authors calculations using respondents age 18 to 79 pooled over the 2013-19 surveys (dark blue bars) or 2020-21 surveys (orange bars). 
Figure 6. Baseline vs. Counterfactual Movements in the AHG and Potential Work Hours (a) Baseline vs. Counterfactual $A H G$

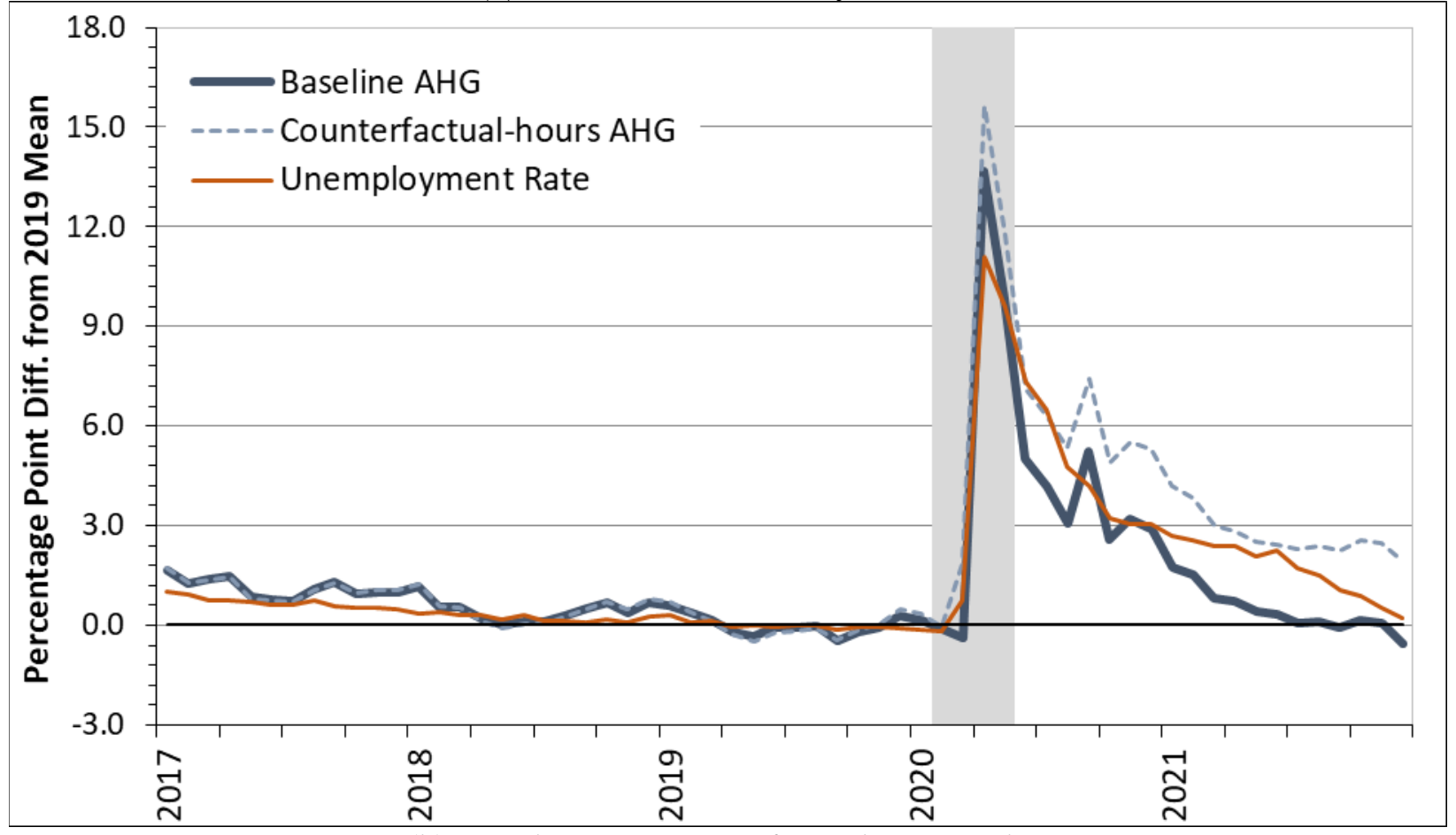

(b) Baseline vs. Counterfactual Potential Hours

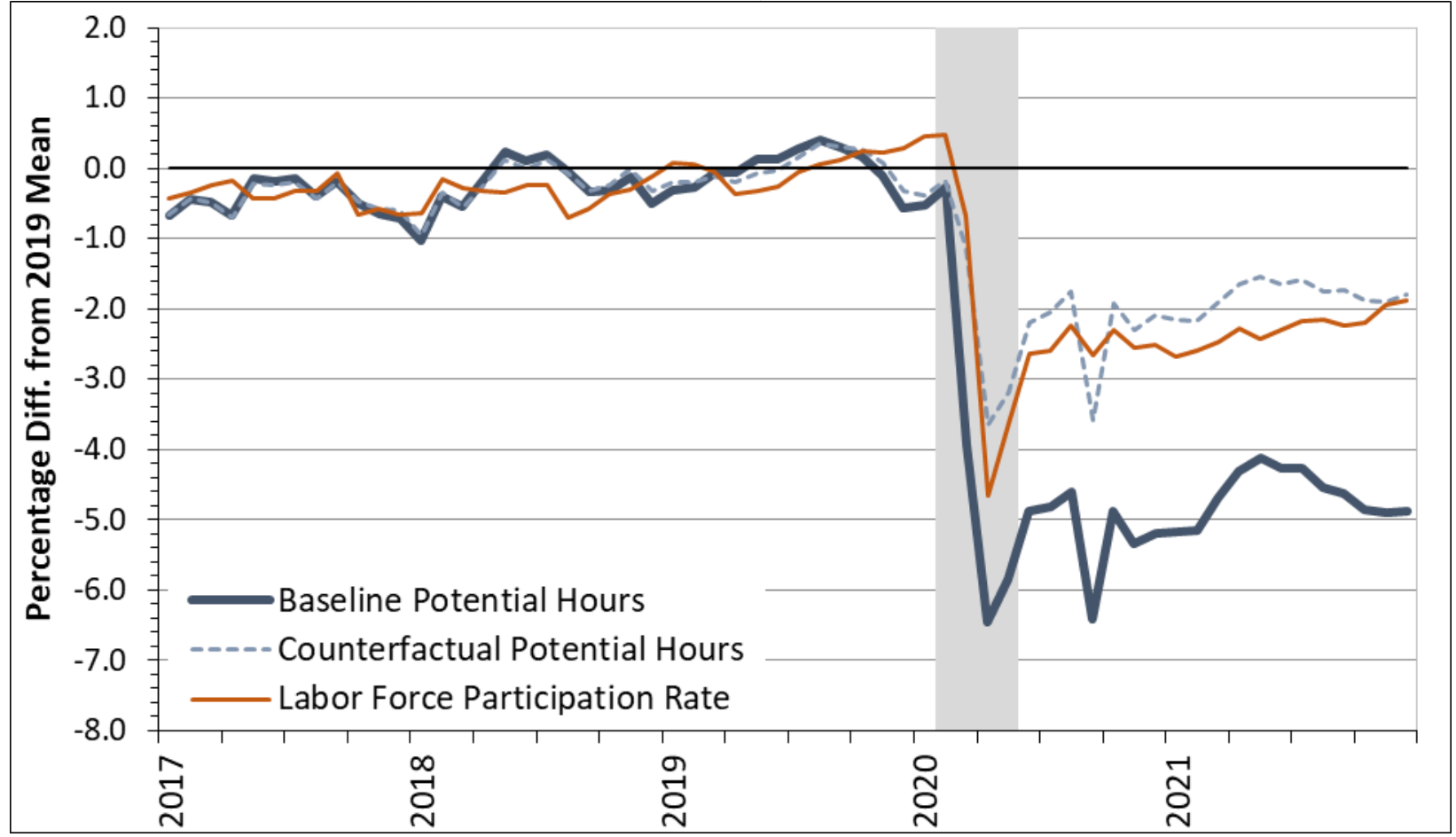

Notes: Estimates are from authors' calculations using CPS and SCE data for all individuals age 18 to 79 . Baseline estimates of the AHG and potential work hours replicate the estimates from Figures 1 and 2, respectively. Counterfactual estimates recalculate each series holding desired hours constant within each labor force status $\times$ demographic estimation cell from March 2020 forward. The unemployment and labor force participation rates use CPS data. See text for details. 
Figure 7. Baseline vs. Counterfactual Movements in the AHG, Additional Detail

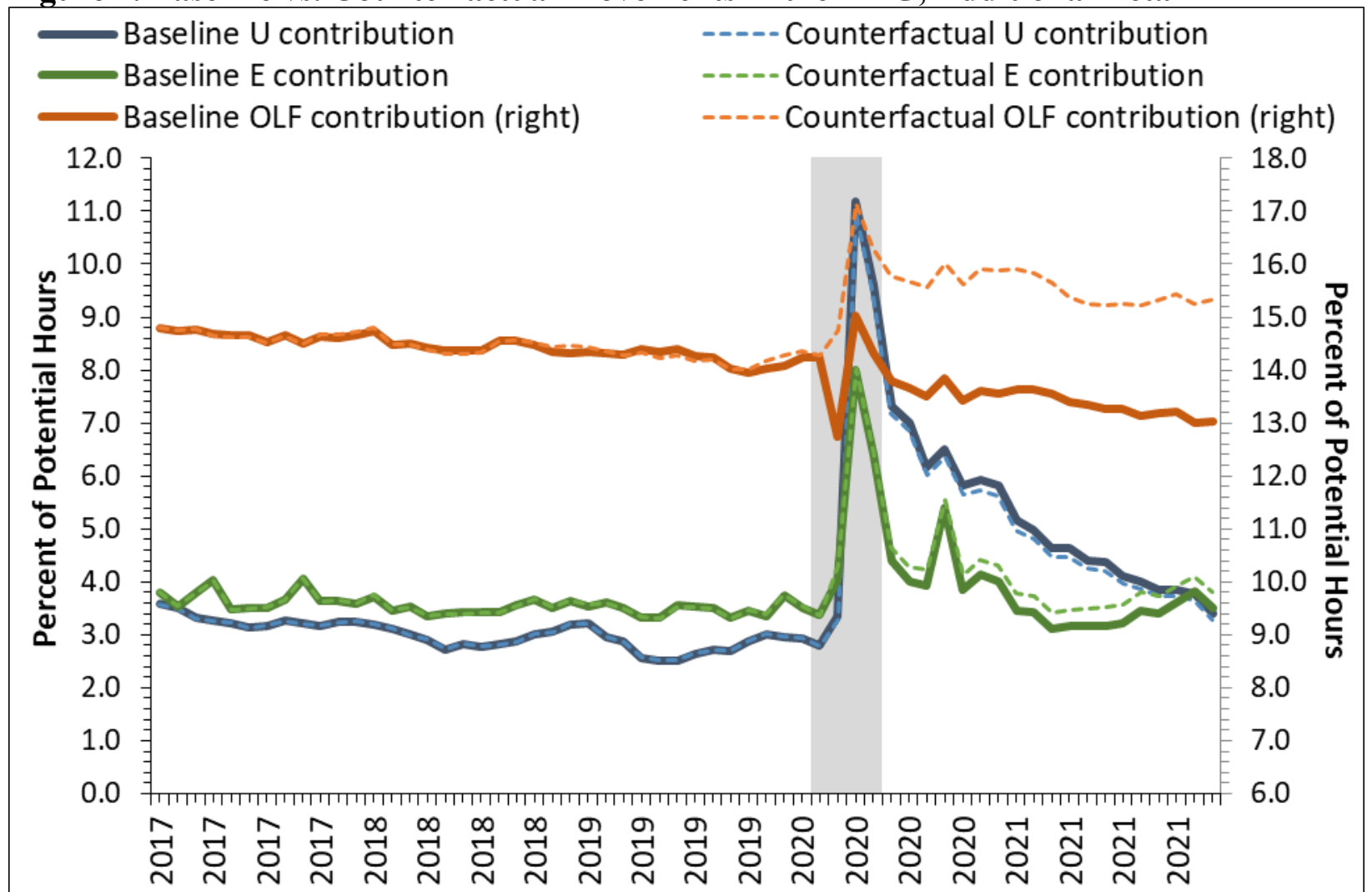

Notes: Estimates are from authors' calculations using CPS and SCE data for all individuals age 18 to 79 . Baseline and counterfactual estimates of the AHG and potential work hours replicate those from Figure 6, with the AHG broken out by labor force state. Counterfactual estimates recalculate each series holding desired hours constant within each labor force status $\times$ demographic estimation cell from March 2020 forward. See text for details. 
Figure 8. Fraction of Those Out of the Labor Force Not Looking Because of Covid

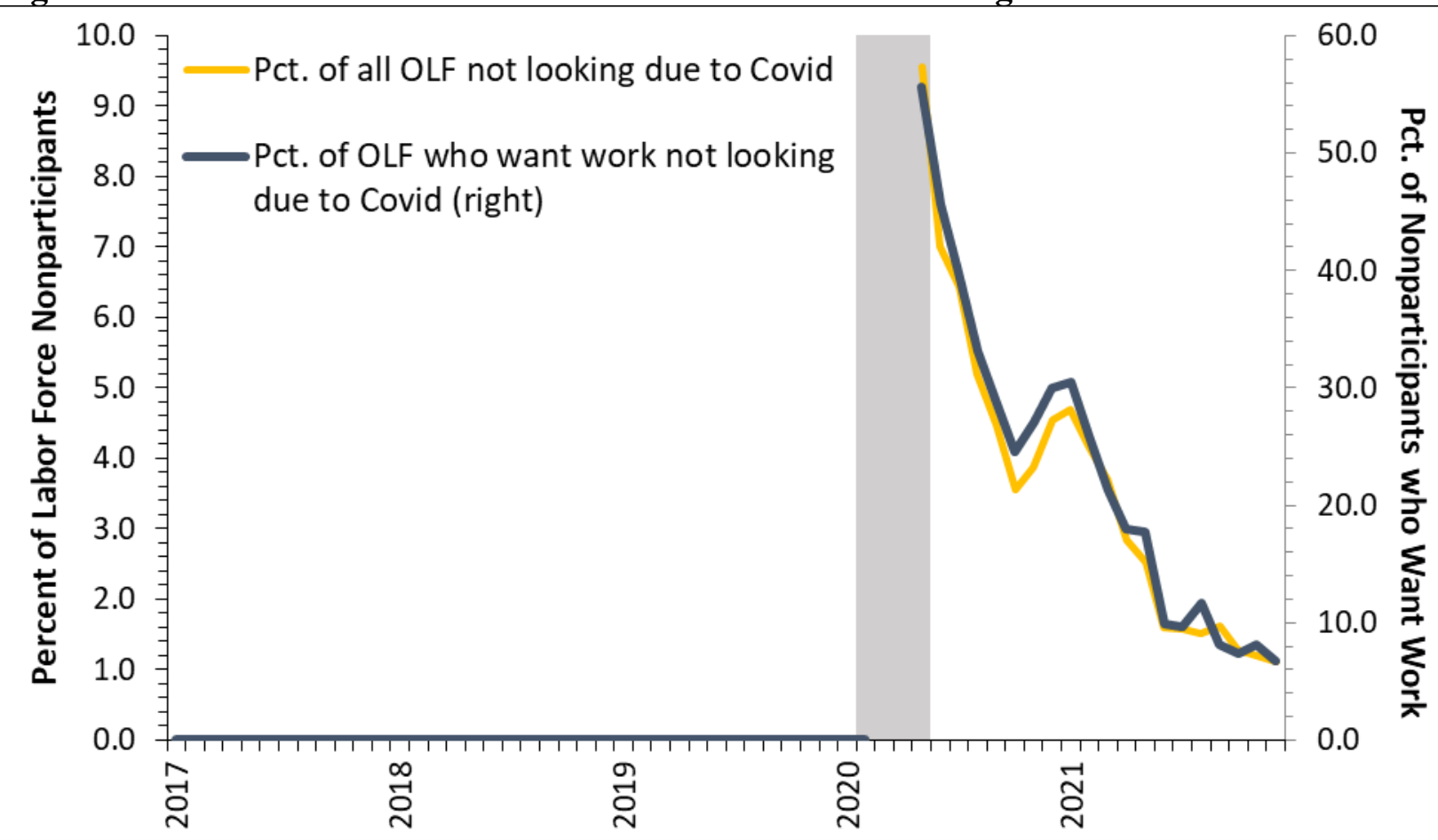

Notes: Estimates are from authors' calculations for all individuals age 18 to 79 in the CPS, based on a special survey question implemented starting in May 2020. 


\section{Appendix: Desired Hours by Demographics and Labor Force Status, 2013-19 vs. 2020-21 Samples}

Table A.1 reports the mean desired hours and (adjusted) hours gaps for the 39 demographics $\times$ labor force status categories that we use in the estimation of our measure of labor market underutilization for the 2013-19 and 2020-21 survey years pooled together. The estimates are for nine different labor force states (as noted in the main text), three age groups (less than 25, 25 to 54,55 or older), gender, and two education groups (less than a college degree or a college degree or more). This creates a potential for up to 108 group estimates of desired work hours. Unfortunately, sparse sample cells limit our ability to generate reliable estimate for all 108 groups. Consequently, we aggregate individuals into 39 broader groups. These groups are an unbalanced panel of demographic subgroups across the nine labor force states. These categories represent the finest level of disaggregation we feel we can use given the sample size constraints. The estimates are the sample-weighted means of desired work hours predicted by labor force status, demographics, and their interaction with a fixed effect for the pandemic period as described in the main text. The table shows considerable heterogeneity in desired hours across the groups, along with notable heterogeneity in the change in desired hours between the 2013-19 and 2020-21 periods. See the Table 1 and its discussion in the main text for more details. 
Table A.1. Desired Hours by Demographics \& Labor Force Groups Used in Estimation

\begin{tabular}{|c|c|c|c|c|c|}
\hline \multirow{2}{*}{$\begin{array}{l}\text { Labor Force } \\
\text { Status }\end{array}$} & \multirow[b]{2}{*}{ Description } & \multicolumn{2}{|c|}{ 2013-19 SCE } & \multicolumn{2}{|c|}{ 2020-21 SCE } \\
\hline & & $N$ & Mean & $N$ & Mean \\
\hline \multirow{10}{*}{$\begin{array}{l}\text { Employed FT, } \\
\text { single job }\end{array}$} & Male, 18-24, all education & 31 & $\begin{array}{l}38.77 \\
(0.13)\end{array}$ & 3 & $\begin{array}{l}29.94 \\
(0.95)\end{array}$ \\
\hline & Male, 25-54, $<$ College & 532 & $\begin{array}{l}37.83 \\
(0.03)\end{array}$ & 124 & $\begin{array}{l}39.36 \\
(0.15)\end{array}$ \\
\hline & Male, $25-54, \geq$ College & 1039 & $\begin{array}{l}37.91 \\
(0.02)\end{array}$ & 323 & $\begin{array}{l}37.65 \\
(0.06)\end{array}$ \\
\hline & Male, $55+,<$ College & 242 & $\begin{array}{l}36.70 \\
(0.04)\end{array}$ & 43 & $\begin{array}{l}38.43 \\
(0.22)\end{array}$ \\
\hline & Male, $55+, \geq$ College & 299 & $\begin{array}{l}36.73 \\
(0.03)\end{array}$ & 58 & $\begin{array}{l}36.68 \\
(0.14)\end{array}$ \\
\hline & Female, 18-24, all education & 47 & $\begin{array}{l}35.37 \\
(0.15)\end{array}$ & 14 & $\begin{array}{l}28.76 \\
(0.49)\end{array}$ \\
\hline & Female, 25-54, < College & 484 & $\begin{array}{l}34.91 \\
(0.04)\end{array}$ & 90 & $\begin{array}{l}37.04 \\
(0.16)\end{array}$ \\
\hline & Female, 25-54, $\geq$ College & 787 & $\begin{array}{l}34.99 \\
(0.03)\end{array}$ & 245 & $\begin{array}{l}35.40 \\
(0.08)\end{array}$ \\
\hline & Female, $55+,<$ College & 181 & $\begin{array}{l}33.35 \\
(0.07)\end{array}$ & 42 & $\begin{array}{l}36.12 \\
(0.15)\end{array}$ \\
\hline & Female, $55+, \geq$ College & 162 & $\begin{array}{l}33.56 \\
(0.07)\end{array}$ & 58 & $\begin{array}{l}34.54 \\
(0.17)\end{array}$ \\
\hline \multirow{6}{*}{$\begin{array}{l}\text { Employed FT, } \\
\text { multiple jobs }\end{array}$} & Male, 18-54, < College & 99 & $\begin{array}{l}39.39 \\
(0.06)\end{array}$ & 22 & $\begin{array}{l}37.89 \\
(0.22)\end{array}$ \\
\hline & Male, $18-54, \geq$ College & 168 & $\begin{array}{l}39.47 \\
(0.05)\end{array}$ & 46 & $\begin{array}{l}36.96 \\
(0.28)\end{array}$ \\
\hline & Male, 55+, all education & 91 & $\begin{array}{l}38.16 \\
(0.05)\end{array}$ & 19 & $\begin{array}{l}37.25 \\
(0.25)\end{array}$ \\
\hline & Male, $18-54,<$ College & 138 & $\begin{array}{l}36.28 \\
(0.09)\end{array}$ & 28 & $\begin{array}{l}36.65 \\
(0.33)\end{array}$ \\
\hline & Male, $18-54, \geq$ College & 202 & $\begin{array}{l}36.41 \\
(0.07)\end{array}$ & 57 & $\begin{array}{l}34.38 \\
(0.21)\end{array}$ \\
\hline & Male, 55+, all education & 73 & $\begin{array}{l}35.01 \\
(0.11)\end{array}$ & 13 & $\begin{array}{l}34.94 \\
(0.42)\end{array}$ \\
\hline \multirow{7}{*}{$\begin{array}{l}\text { Employed PT, } \\
\text { single job }\end{array}$} & Male, 18-54, all education & 100 & $\begin{array}{l}26.63 \\
(0.07)\end{array}$ & 26 & $\begin{array}{l}23.09 \\
(0.48)\end{array}$ \\
\hline & Male, $55+,<$ College & 103 & $\begin{array}{l}25.25 \\
(0.05)\end{array}$ & 16 & $\begin{array}{l}22.72 \\
(0.34)\end{array}$ \\
\hline & Male, $55+, \geq$ College & 138 & $\begin{array}{l}25.19 \\
(0.03)\end{array}$ & 34 & $\begin{array}{l}21.23 \\
(0.25)\end{array}$ \\
\hline & Female, 18-54, < College & 119 & $\begin{array}{l}23.53 \\
(0.09)\end{array}$ & 32 & $\begin{array}{l}20.48 \\
(0.69)\end{array}$ \\
\hline & Female, 18-54, $\geq$ College & 123 & $\begin{array}{l}23.71 \\
(0.08)\end{array}$ & 33 & $\begin{array}{l}20.41 \\
(0.24)\end{array}$ \\
\hline & Female, $55+,<$ College & 94 & $\begin{array}{l}21.95 \\
(0.09)\end{array}$ & 36 & $\begin{array}{l}20.70 \\
(0.23)\end{array}$ \\
\hline & Female, $55+, \geq$ College & 92 & $\begin{array}{l}21.84 \\
(0.09)\end{array}$ & 20 & $\begin{array}{c}18.98 \\
(0.28)\end{array}$ \\
\hline
\end{tabular}

(continued on next page) 
Table A.1. (continued)

\begin{tabular}{|c|c|c|c|c|c|}
\hline \multirow{2}{*}{$\begin{array}{l}\text { Labor Force } \\
\text { Status }\end{array}$} & \multirow[b]{2}{*}{ Description } & \multicolumn{2}{|c|}{ 2013-19 SCE } & \multicolumn{2}{|c|}{ 2020-21 SCE } \\
\hline & & $N$ & Mean & $N$ & Mean \\
\hline \multirow{2}{*}{$\begin{array}{l}\text { Employed PT, } \\
\text { multiple jobs }\end{array}$} & Male, all ages, all education & 118 & $\begin{array}{l}30.25 \\
(0.12)\end{array}$ & 15 & $\begin{array}{l}27.30 \\
(0.52)\end{array}$ \\
\hline & Female, all ages, all education & 164 & $\begin{array}{l}27.03 \\
(0.09) \\
\end{array}$ & 34 & $\begin{array}{l}24.76 \\
(0.57)\end{array}$ \\
\hline \multirow{2}{*}{$\begin{array}{l}\text { Unemployed } \\
\leq 6 \text { months }\end{array}$} & Male, all ages, all education & 54 & $\begin{array}{l}38.90 \\
(0.31)\end{array}$ & 18 & $\begin{array}{l}37.92 \\
(0.51)\end{array}$ \\
\hline & Female, all ages, all education & 91 & $\begin{array}{l}34.06 \\
(0.27)\end{array}$ & 30 & $\begin{array}{l}34.05 \\
(0.71)\end{array}$ \\
\hline \multirow{2}{*}{$\begin{array}{l}\text { Unemployed } \\
>6 \text { months }\end{array}$} & Male, all ages, all education & 39 & $\begin{array}{l}37.68 \\
(0.42)\end{array}$ & 10 & $\begin{array}{l}38.30 \\
(0.29)\end{array}$ \\
\hline & Female, all ages, all education & 40 & $\begin{array}{l}33.89 \\
(0.51) \\
\end{array}$ & 13 & $\begin{array}{l}36.09 \\
(1.02) \\
\end{array}$ \\
\hline \multirow{2}{*}{$\begin{array}{l}\text { OLF, Want } \\
\text { Work }\end{array}$} & Male, all ages, all education & 26 & $\begin{array}{l}30.37 \\
(0.59)\end{array}$ & 13 & $\begin{array}{l}29.09 \\
(1.10)\end{array}$ \\
\hline & Female, all ages, all education & 32 & $\begin{array}{l}29.63 \\
(0.62) \\
\end{array}$ & 13 & $\begin{array}{r}26.54 \\
(0.71)\end{array}$ \\
\hline \multirow{4}{*}{ OLF, Retired } & Male, all ages, $<$ College & 425 & $\begin{array}{l}11.59 \\
(0.08)\end{array}$ & 92 & $\begin{array}{l}10.52 \\
(0.13)\end{array}$ \\
\hline & Male, all ages, $\geq$ College & 492 & $\begin{array}{l}10.95 \\
(0.07)\end{array}$ & 128 & $\begin{array}{l}8.28 \\
(0.09)\end{array}$ \\
\hline & Female, all ages, $<$ College & 334 & $\begin{array}{l}10.08 \\
(0.10)\end{array}$ & 88 & $\begin{array}{l}10.07 \\
(0.17)\end{array}$ \\
\hline & Female, all ages, $\geq$ College & 240 & $\begin{array}{c}9.78 \\
(0.12)\end{array}$ & 69 & $\begin{array}{c}8.10 \\
(0.18) \\
\end{array}$ \\
\hline \multirow{4}{*}{ OLF, Other } & Male, $18-54$, all education & 102 & $\begin{array}{l}17.80 \\
(0.18)\end{array}$ & 27 & $\begin{array}{l}13.02 \\
(0.27)\end{array}$ \\
\hline & Male, $55+$ all education & 106 & $\begin{array}{l}13.33 \\
(0.20)\end{array}$ & 18 & $\begin{array}{c}9.22 \\
(0.40)\end{array}$ \\
\hline & Female, 18-54, all education & 282 & $\begin{array}{l}16.57 \\
(0.13)\end{array}$ & 54 & $\begin{array}{l}13.15 \\
(0.31)\end{array}$ \\
\hline & Female, $55+$ all education & 132 & $\begin{array}{l}11.93 \\
(0.18)\end{array}$ & 42 & $\begin{array}{l}9.36 \\
(0.30)\end{array}$ \\
\hline
\end{tabular}

Notes: Sample is all individuals in the SCE Job Search supplement aged 18-79 pooled across its 2013-19 and 2020-21 surveys. Estimates represent the sample-weighted mean predicted desired hours, where the predicted estimates are from the regression of actual desired hours on fixed effects for labor force status, demographics, and time period. See the main text for details. Standard errors are in parentheses. 